\title{
Halilürrahman Vakfı'nın 18. Yüzyıl Başında Mali Durumu
}

\section{The Financal Situation of the Halilurrahman Waqf In Hebron at the Beginning of the $18^{\text {th }}$ Century}

\section{Şerife Eroğlu Memiş* (i)}

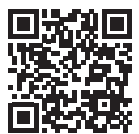

*Dr., Ankara Hacı Bayram Veli Üniversitesi, Edebiyat Fakültesi, Tarih Bölümü Ankara, Türkiye

ORCID: Ş.E.M. 0000-0003-2880-8602

Sorumlu yazar/Corresponding author: Şerife Eroğlu Memiş,

Ankara Hacı Bayram Veli Üniversitesi, Edebiyat Fakültesi, Tarih Bölümü, Ankara, Türkiye

E-posta/E-mail: serife_eroglu@yahoo.com

Başvuru/Submitted: 29.04 .2020 Revizyon Talebi/Revision Requested: 23.10.2020

Son Revizyon/Last Revision Received:

25.10.2020

Kabul/Accepted: 06.11 .2020

\section{Atıf/Citation:}

Eroglu Memis, Serife. "Halilürrahman Vakfínın 18. Yüzyıl Başında Mali Durumu." Tarih Dergisi Turkish Journal of History, 72 (2020): 77-114. https://doi.org/10.26650/iutd.729410

\section{ÖZ}

El-Halil şehrinde bulunan Halilürrahman Vakfı başta İbrahim Peygamber olmak üzere pek çok peygamberin türbesi üzerine kurulmuş olan el-Halil Camii ve Halil İbrahim Sofrası'nı bünyesinde barındırmaktadır. Gelirlerinin büyük kısmını kırsal kaynaklardan elde eden bu vakıf, bölgesel ekonomiyi etkilemekte ve desteklemektedir. Bu çalışma vakfa ait 1117-1118/1705-1707 ile 1118/17071708 tarihli muhasebe kayıtları üzerinden vakfın ekonomik ve sosyal yapısını, verdiği hizmetin devamının nasıl sağlandığını, oluşturduğu istihdam hacmini, dönemin fiyatlarını ve ücretlerini incelemeyi amaçlamaktadır.

Anahtar sözcükler: El-Halil, Halilürrahman, Muhasebe, Vakıf, Osmanlı Tarihi

\section{ABSTRACT}

The Halilurrahman Waqf, located in the city of Hebron, contains the al-Khalil Mosque and public kitchen of al-Khalil, built on the tombs of many prophets, importantly the Prophet Abraham. This waqf, which receives most of its income from rural resources, affects and supports the regional economy. This study aims to examine the economic and social structure of the waqf, the continuation of the services it provides, the employment volume it generates, and the prices and fees of the period through the accounting records of the waqf dated 1117-1118/1705-1707 and 1118/1707-1708.

Keywords: Hebron, Halilurrahman, Accounting, Waqf, Ottoman History 


\section{Extended Abstract}

In 1517, after the Syria, Egypt and Hijaz expeditions of Yavuz Sultan Selim, the city of Hebron joined the Ottoman lands. Necessary repairs were made in the city visited by Sultan Selim I. The southwestern part of western Palestine, or Damascus province, was then divided into four main sanjaks at that time: Gaza, Laccun (northern valleys), Nablus, and Jerusalem. In this administrative and military structure of the Ottoman administration, $a l$ Khalil was transformed into a township linked to the Sanjak of Jerusalem. The borders of the Jerusalem sanjak extending to al-Khalil in the south stretched from Ramlah in the north and from Jaffa on the Mediterranean coast to the east of the city from the valley of Jericho and Jordan. Throughout the century, minor border changes have occurred, but in general, this administrative and military division remained largely unchanged from the Ottoman conquest until the 18 th century.

With the conquest of Syria, Egypt and Hejaz during the reign of Selim I, the administration and organization of the pilgrimage passed to the Ottoman State. After that, the Ottomans had an empire spanning three continents and had achieved the status of being the religious leader of Muslim countries. The mid-16th century was a turning point in the attitude of the Ottoman administration center towards the south of Bilad al-Sham as a whole. The activities of Suleiman the Magnificent in these areas should be seen within the framework of practices aimed at integrating the region into a developing Ottoman state and administration approach. The most important part of the ideal of integrating this newly conquered geography into the imperial imagination was the pilgrimage organization. In the half century after the conquest, a significant number of attempts were made by the imperial center to attract pilgrims or facilitate travel in these areas. The activities carried out in Khasseki Sultan Imâret (Public Kitchen) in Jerusalem and Simât al-Kalîl (Table of Abraham) in Hebron should be seen as important components of this ideal. Because the public kitchens in Jerusalem and al-Khalil were quite large and they played important roles in ensuring the continuity of the pilgrims coming to the holy cities and meeting their needs. Moreover, caravanserais, inns and baths built in the 18th century, -along the roads passing passing from Istanbul to Damascus, from there to Madinah and Mecca, Jerusalem and al-Khalil within the framework of the pilgrimage organization operated with a certain degree of order. The construction of cities, towns and ranges is important in terms of showing the point this viewpoint has reached.

The Halilurrahman Waqf, which was also known as the Table of Abraham, was a waqfcomplex that also included the al-Halil Mosque, which was built on the tombs of many prophets, importantly, Abraham the Prophet.

Muslim pilgrims who visited Mecca and Medina for centuries with the intention of pilgrimage came to Bayt al-Mukaddis, whose virtues were praised in verses and hadiths, 
and which were recommended to be visited, with the intention of gaining more rewards. The abundance and contact with $m i$ 'râc of this town, which is "blessed" in the Qur'an, has always been a center of attraction for all Muslims and especially Sufis. The importance of these towns, which have held a special and sacred place for Muslim visitors since the early years of Islam, was fixed with hadiths and was shaped by local traditions. Since the route from Istanbul to Mecca is close to the route, Ottoman pilgrims also frequently visited the cities of Jerusalem and al-Khalil while going on pilgrimage. Due to the location of the city of al-Khalil on these pilgrimage roads and the graves of the prophets found here, visitors from all over the Islamic world were welcomed at the Table of Abraham because they were regarded as guests of Allah. Although it was not a sultan or vizier waqf, the Halilurrahman Waqf was a large-budget waqf, which had important income sources in terms of both the city of al-Khalil and the region in which it was located, and those who came to the city, especially the pilgrims, sufis and travelers, were fed in the Table of Abraham. The inn, baths and shops allocated of the cities of the waqf al-Khalil, Jerusalem, Gaza and Ramlah constitute the revenues of the foundation for urban origin. These revenues were around 103,572 para in 1117-1118 / 1705-1707. However, the waqf obtained revenues in excess of 900,000 para in the same year mainly from rural sources. With this budget size, the services it saw and the employment volume of more than two hundred people, the foundation provided serious amounts to the economy of the city of al-Khalil through purchases of goods and services and salary payments. With the enormous revenues of the villages devoted to it, the foundation had a central position and an important weight in the agricultural economy of the region. With these assets, the foundation was in a position to affect and support the regional and urban economy.

For this reason, the control and monitoring mechanism of this waqf, which was controlled by the Ottoman central administration, was more careful and versatile than the mechanism of ordinary waqfs. The most effective tool in this mechanism was the accounting system, which consisted of the annual main accounting book and various detailed records kept according to the standard posting principles. Depending on the accounting, the control and monitoring mechanism had been effective according to the standards of its time, thanks to the officers and auditors responsible for waqf accounting. In addition, although the waqf's accounts were submitted to the mutawalli of the waqf every year, it was always possible to supervise the waqf accounting by the representatives of the supervisory authorities, and by local judges, usually following a complaint.

Accounting records are important as they are one of the main archive sources to reestablish an organization's actual functioning. Moreover, accounting records have entered the workspace of the historian, considering that the effectiveness of accounting control is seen as a factor that leads to institutional effectiveness and that accounting records reflect 
corporate development and change. Recently, international publications and symposiums on accounting applications with different approaches and conceptual frameworks have increased and created a new literature. However, it is noteworthy that there are few investigations regarding the accounting practices of the Ottoman Empire, which had a well-established accounting tradition and kept its records in archives. This may be due to the fact that researchers of accounting origin rather than historians turn to the history of accounting, while historians see only the records as material of institutional, economic and financial history.

On the other hand, independent studies on Hebron and its waqfs in the Ottoman period are few in number. In addition, there are studies examining Jerusalem and al-Khalil within the framework of the surras sent to "al-Haramayn". In this context, it is aimed to determine the financial status of the waqf at the beginning of the 18th century by examining the subsequent accounting records of the current study Halilurrahman Waqf. Thus, within the framework of the study aiming to contribute to the existing literature on the city and waqfs of al-Khalil in the Ottoman period, accounting books have been included, which are valuable resources for waqfs as well as for social and economic history, in terms of providing information about the social and economic conditions of the waqf. The records were applied within the boundaries of this article in the context of the Halilurrahman Waqf.

As a result of the current study, the total income and expense figures in the two accounting records of the Halilurrahman Waqf dating to the beginning of the 18th century were created and then the method of decomposing them was used to develop a detailed analysis. Thus, foundation village revenues, cash surplus and uncollected revenues from the previous year, which constituted waqf revenues, are stated separately. Personnel expenses, storehouse, kitchen, lighting expenses, repair expenses and miscellaneous expenses, which constituted the waqf expenses together, are also expressed. These accounts show us the diversity and composition of the income sources of the Halilurrahman Waqf in Hebron. In addition, the data obtained from these income records enable us to follow the financial status of the waqf. Examination of the expense side of the accounting books completed the waqf financial statement. Expenditures for food and other products consumed regularly in the public kitchen provided us with important information in terms of the operation and services of the waqfcomplex of Hebron. 


\section{Giriş}

1517 yılında Yavuz Sultan Selim'in Suriye, Misır ve Hicaz seferleri sonrası el-Halil kenti Osmanlı topraklarına katılmıştı. Sultan I. Selim tarafından ziyaret edilen kentte gerekli tamirat yapılmıştı ${ }^{1}$. Batı Filistin ya da Şam eyaletinin güneybatı kısmı, o zamanlar başlıca dört sancağa ayrılmıştı: Gazze, Laccun (kuzey vadileri), Nablus ve Kudüs. El-Halil, Osmanlı yönetiminin bu idari ve askeri yapılanmasında Kudüs Sancağı'na bağlı bir nâhiye haline getirilmiştir². Güneyde el-Halil'e uzanan Kudüs sancağının sınırları, kuzeyde Remle'den ve Akdeniz kıyısındaki Yafa'dan Eriha ve Ürdün vadisinden kentin doğusuna uzanıyordu. Yüzyıl süresince önemsiz sınır değişiklikleri oldu; ancak genel olarak bu idari ve askeri bölümlenme Osmanlı fethinden 18. yüzyıla dek büyük ölçüde değişmeden kaldı .

I. Selim döneminde Suriye, Mısır ve Hicaz'ın ele geçirilmesi ile aynı zamanda da haccın idaresi ve organizasyonu Osmanlı Devleti’ne geçti. 16. yüzyıl ortaları Osmanlı yönetim merkezinin bir bütün olarak Bilâdü'ş-Şam'ın güneyine yönelik tutumlarında bir dönüm noktası olmuştur. Yeni fethedilen bu coğrafyayı imparatorluk muhayyilesine entegre etmek idealinin en önemli ayağını ise hac organizasyonu oluşturmuştur. Fetihten sonraki yarım yüzyılda, hacıların bu bölgede seyahatini kolaylaştırmak için imparatorluk merkezince önemli sayıda girişimler gerçekleştirilmiştir ${ }^{4}$. Kudüs’te bulunan Haseki Sultan İmareti ile el-Halil'de bulunan Simâtü'l-Halîl (Halil İbrahim Sofrası)'nda yürütülen faaliyetleri bu idealin önemli bileşenleri olarak görmek gerekir. Zira Kudüs ve el-Halil'de bulunan imâretler oldukça büyüktü ve kutsal şehirlere gelen hacıların devamlılığının sağlanması ve ihtiyaçlarının karşılanması konusunda önemli rolleri icra etmekte idi. Öte yandan 18. yüzyıla kadar hac organizasyonu çerçevesinde İstanbul'dan Şam'a, oradan Medine ve Mekke'ye, Kudüs'e ve el-Halil'e geçilen yollar boyunca inşa edilen kervansaraylar, hanlar ve hamamlar, şehirler, kasabalar ve menzilhâneler bu bakış açısının ulaştığı noktayı göstermesi bakımından önemlidir 5 .

1 Mustafa L. Bilge, "Halil", DIA, c. XV, İstanbul 1997, s. 305-306.

2 Ahmet Akgündüz, Osmanlı Kanunnameleri, İstanbul 1994, c. VII, s. 21.

3 Dror Ze'evi, XVII. Yüzyllda Bir Osmanlı Sancağında Toplum ve Ekonomi, Tarih Vakfi Yurt Yay., İstanbul 2000, s. 11-12.

4 Astrid Meier, "For the Sake of God Alone? Food Distribution Policies, Takiyyas and Imarets in Early Ottoman Damascus", in Feeding People, Feeding Power: Imarets in the Ottoman Empire, ed. Nina Ergin, Christoph K. Neumann, Amy Singer, Eren Yayınları, İstanbul 2007, s. 122-123.

5 Hac yolunun düzenlenmesine ilişkin bazı incelemeler için bkz. Yusuf Halaçoğlu, Osmanlı İmparatorluğunda Menzil Teşkilatı ve Yol Sistemi, İstanbul Üniversitesi Edebiyat Fakültesi Yay., İstanbul 1982, s. 4-5; İ. Hakkı Uzunçarşıll, Mekke-i Mükerreme Emirleri, Ankara 1972, s. 40-42; Münir Atalar, Osmanlı Devleti'nde Surre-i Hümâyûn ve Surre Alayları, Diyanet İșleri Başkanlığı Yayınları, Ankara 1991, s. 129; A. Latif Armağan, "XVIII. Yüzyılda Hac Yolu Güzergâhı ve Menziller", Osmanlı Araş̧tırmaları, sayı XX (İstanbul 2000), s. 73-76. Osmanlıların Anadolu'da ve Rumeli'de yol güzergâhlarında, özellikle dağlı ve geçit bölgelerinde, halkın can, mal ve namus emniyetini sağlamak için kurdukları teşkilata "derbend", bu teşkilatta görevli olan kimseye de "derbendci" denilirdi. Bkz. Mehmed Zeki Pakalın, Osmanlı Tarih Deyimleri ve Terimleri Sözlüğü, c. I, MEB Yay., İstanbul 2004, s. 425; Cengiz Orhonlu, Osmanlı İmparatorluğunda Derbend Teşkilatı, Eren Yay., İstanbul 1990), s. 65, 75-100; Muhammad Adnan Bakhit, The Ottoman Province of Damascus in the Sixteenth Century, Librairie du Liban, Beirut 1982, s. 100. 
Halil İbrahim Sofrası olarak da bilinen imâreti bünyesinde bulunduran Halilürrahman Vakfı başta Hz. İbrahim olmak üzere pek çok peygamberin türbesi üzerine kurulmuş olan el-Halil Camii'ni de içeren bir vakıf-külliye idi ${ }^{6}$.

Yüzyıllar boyunca hac niyeti ile Mekke ve Medine'yi ziyaret eden Müslüman hacılar ise, ayet ve hadislerde faziletleri övülen, ziyaret edilmesi tavsiye edilen Beytü'l-Mukaddes'e “kesr-i sevâb" niyetiyle gelmişlerdir. Kur'an-1 Kerim'de “etrafı mübarek kılınan ” bu beldenin bereketi ve Mi'râc ile olan irtibatı genelde bütün Müslümanlar ve husûsen de sûfîler için her daim bir çekim merkezi olmuştur. İstanbul'dan Mekke'ye giden güzergâha yakın olduğu için Osmanlı hacıları da hacca giderken Kudüs ve el-Halil kentlerini sık sık ziyaret etmişlerdir? El-Halil şehrinin bu hac yolları üzerindeki konumu ve burada bulunan peygamber kabirleri nedeniyle İslâm dünyasının dört bir yanından yıl boyunca gelen ziyaretçiler, Allah misafiri sayıldığı için Halil İbrahim Sofrası'nda ağırlanırlardı. Sultan ya da vüzerâ vakfi ${ }^{8}$ olmamasına rağmen, Halilürrahman Vakfı, hem el-Halil şehri hem de bulunduğu coğrafya bakımından önemli gelir kaynakları olan, fakir ve muhtaçların yanı sıra hacı, sufi ve seyyahlar başta olmak üzere kente gelenlerin de İbrahim Peygamber'in simâtında doyurulduğu büyük bütçeli bir vakıftı. Vakfa el-Halil, Kudüs, Gazze ve Remle şehirlerinden tahsis edilen han, hamam ve dükkânlar vakfın kentsel kökenli gelirlerini oluşturmaktadır. Bu gelirler 11171118/1705-1707 yıllarında 103.572 para civarındadır. Ancak vakıf aynı yıl 900.000 parayı aşan gelirlerini esasen kırsal kaynaklardan temin etmektedir. Bu bütçe büyüklüğü, gördüğü hizmetler ve iki yüz kişinin üstünde istihdam hacmi ile vakıf, el-Halil kenti ekonomisine mal ve hizmet satın alımları ve maaş ödemeleri yoluyla ciddi meblağlar akıtmaktadır. Kendisine vakfedilmiş köylerin muazzam gelirleri ile de vakıf, bölgenin tarımsal ekonomisinde merkezi bir konuma, önemli bir ağırlığa sahiptir.

Bu nedenle, Osmanlı merkezi yönetimi tarafından denetlenen bu vakfın kontrol ve izleme mekanizması sıradan vakıfların mekanizmasından daha dikkatli ve çok yönlü olmuştur. Bu mekanizmada en etkili araç ayrıntılı kayıtlardan oluşan muhasebe sistemidir ${ }^{10}$. Kontrol ve izleme mekanizması vakıf muhasebesinden sorumlu görevliler ve denetçiler sayesinde

6 Abdüsselam Uluçam, "Haremü'l- Halîl", DİA, c. XV, İstanbul 1997, s. 308.

7 Şerife Eroğlu Memiş, “Nebzetü'l-Menâsik': en-Nakşibendî el-Muradî’nin Hac Rehberi’nde Kudüs Bahsi”, Dini Tarihi ve Edebi Açıdan Kudüs, DBY Yay., İstanbul 2018, s. 170-173.

8 Sultan ve vüzerâ vakıfları tasnifi hakkında detaylı bilgi için bkz. Kayhan Orbay, "Vakıf Muhasebesi ve Kurumsal Etkinlik: Kayıt Sistemi, Defterler, Denetim”, XVII. Türk Tarih Kongresi, Ankara, Türkiye, 15 - 17 Eylül 2014, c. IV, no. 5, s. 1719.

9 Kayhan Orbay, "Imperial Waqfs within the Ottoman Waqf System", Endowment Studies, I/2 (2017), s. 145146.

10 Oktay Güvemli - Batuhan Güvemli, "Osmanlı Kayıt Kültüründe Vakıf muhasebesi ve Devlet Muhasebe Sistemi", Vakfflar Dergisi, say1 46 (2016), s. 9-10; Orbay, "Imperial Waqfs", s. 145-146; Fatma Şensoy, "Ebubekir Paşa'nın İstanbul'daki Sıbyan Mektebi ve Sbil Vakfı'nın 1867-68 Yıllarına Ait Muhasebe Defterleri Üzerinden Vakıflardaki Kayıt Düzeni ve Dinamik Yapı”, Akademik İncelemeler Dergisi, 13 (1), Sakarya 2018, s. 391-416. 
zamanının standartlarına göre yapılmıştır. Örneğin, 17 Safer 1193/6 Mart 1779 tarihinde Haremeyn Evkâfı Nâzırı Darüssaade Ağası el-Hac Beşir Ağa'nın arzı üzerine Divân-1 Hümâyûn'dan gönderilen bir hükümde vakfın muhasebesi görülürken hazır bulunmak üzere mübâşir-i hâssa adı ile İstanbul'dan bir görevlinin atandığ 1 kayıtlıdır ${ }^{11}$. Ayrıca, vakfın hesapları yılda bir kez vakfın mütevellisine sunulduğu gibi yerel kadılar tarafından vakıf muhasebesinin denetlenmesi her zaman mümkün olabilmiştir ${ }^{12}$.

Öte yandan, muhasebe kayıtları bir kurumun fiili işleyişini yeniden kurmanın temel arşiv kaynaklarından biri olduğu için önemlidir ${ }^{13}$. Aynı zamanda muhasebe denetiminin etkinliği kurumsal etkinliği doğuran bir faktör olarak görüldüğünden ve muhasebe kayıtlarının kurumsal gelişim ve değişimi yansıttığı kabulünden hareketle muhasebe kayıtları tarihçinin çalışma alanına girmiştir. Son zamanlarda farklı yaklaşımlar ve kavramsal çerçeveler ile muhasebe uygulamalarına yönelik uluslararası yayınlar ve sempozyumlar artmış ve yeni bir külliyat oluşturmuştur ${ }^{14}$. Orbay, bu külliyat içerisinde hem köklü bir muhasebe geleneği hem de kayıtlarını arşivlerde muhafaza etmiş olan Osmanlı İmparatorluğu'nun muhasebe uygulamaları hakkında incelemelerin azlığına dikkat çekmiştir. Bu durumu da tarihçilerden çok muhasebe kökenli araştırmacıların muhasebe tarihine yönelmesi, tarihçilerin ise kayıtları sadece veya önemli ölçüde kurumsal, iktisadi ve mali tarihin malzemesi olarak görmelerine bağlamaktadır ${ }^{15}$.

Bununla birlikte, vakıf muhasebe kayıtları çeşitli yöntemlerle incelenmiştir. Bunlardan Barkan, defterlerden bazı örnekleri yayınlamak yoluna giderken, defterlerin yapı ve içerikleri ile ilgili açıklamalar yapmış ve defterlerdeki bazı bilgi ve verileri de düzenleyerek karşılaştırmalı analizler sunmuştur ${ }^{16}$. Farklı bir yöntemle defterleri ele alan Faroqhi ise belirli bir vakfın iktisadi gelişimini ayrıntılı olarak izlemek amacıyla seri vakıf muhasebe

11 VGMA, 814, 144-145.

12 Orbay, "Imperial Waqfs", s. 146.

13 Kayıtlara ilişsin detaylı incelemeler için bkz. Kayhan Orbay, "Structure and the Content of the Waqf Account Books as sources for Ottoman Economic and Institutional History", Turcica, Revue D'Etudes Turques, 39 (2007), s. 3-48; ayn.yzr., "Account Books of the Imperial Waqfs (Charitable Endowments) in the Eastern Mediterranean (15th to 19th Centuries)", Accounting Historians Journal, 40 (2013), s. 31-50.

14 Orbay, "Vakıf Muhasebesi ve Kurumsal Etkinlik", s. 1722.

15 Orbay, s. 1722.

16 Vakıf muhasebe defterlerinin tarihi belgeler olarak önemini vurgulayan çalışmalar için bkz. Ömer Lütfi Barkan, "İmaret Sitelerinin Kuruluș ve İșleyiș Tarzına Ait Araștırmalar", İstanbul Üniversitesi İktisat Fakültesi Mecmuası, XXIII/1-2 (1962-63), s. 243-246; ayn.yzr., "Edirne ve Civarındaki Bazı İmaret Tesislerinin Yıllık Muhasebe Bilançoları", Belgeler, I/2 (1964), s. 237-239; ayn.yzr., "Süleymaniye Cami ve imareti Tesislerine Ait Yıllık Bir Muhasebe Bilançosu 993/994 (1585/1586)", Vakıflar Dergisi, say1 9 (1971), s. 109-112; ayn. yzr., "Fatih Cami ve İmareti Tesislerinin 1489-1490 Y1llarına Ait Muhasebe Bilançoları", İstanbul Üniversitesi İktisat Fakültesi Mecmuası, XXIII/1-2 (1962-63), s. 297-341; ayn.yzr., “Ayasofya Cami’i ve Eyüb Türbesinin 1489-1491 yıllarına ait Muhasebe Bilançoları”, Ístanbul Üniversitesi iktisat Fakültesi Mecmuası, XXIII/1-2 (1962-63), s. 342-379. 
defterlerini analiz etmiştir ${ }^{17}$. Gerber ve Marcus'un çalışmaları da muhasebe defterlerinden yararlanarak vakıfları kent ekonomisine yerleştiren çalışmalardır ${ }^{18}$. Orbay ise, başta sultan ve vüzerâ vakıfları olmak üzere hem seri halinde vakıf muhasebe defterlerini analiz etmiş, hem de muhasebe defterlerinin sosyal ve iktisadi açıdan tarih incelemelerinde daha fazla çalışılmasına yönelik fikir ve öneriler sunmuştur ${ }^{19}$. Son dönemde yapılan bazı çalışmalarda ise kayıt tutuş usulleri çeşitli vakıf kayıt ve belgeleri üzerinden incelenmiştir ${ }^{20}$.

Öte yandan, Osmanlı döneminde el-Halil kenti ve vakıflarına ilişkin müstakil çalışmalar sayıca azdır. Halilürrahman vakıfları ile ilgili en tafsilatlı çalışmalar arasında Güler ve danışmanlığında hazırlanan bazı yüksek lisans çalışmaları sayılabilir²1. Bunun yanı sıra Haremeyn'e gönderilen surreler çerçevesinde Kudüs ve el-Halil surrelerini inceleyen çalışmalar da mevcuttur ${ }^{22}$.

17 Muhasebe defterlerinin diğer arşiv kaynakları ile birlikte kullanıldığı çalışmalar için bkz. Suraiya Faroqhi, "Vakıf Administration in Sixteenth Century Konya, The Zaviye of Sadreddin-i Konevi", Journal of the Economic and Social History of the Orient, XVII/2 (1974), s. 145-172; ayn.yzr., "Seyyid Gazi Revisited: The Foundation as Seen Through Sixteenth and Seventeenth Century Documents", Turcica, 1981, s. 90-121; Kayhan Orbay, The Financial Administration of an Imperial Waqf in an Age of Crisis: A Case Study of Bâyezîd II's Waqf in Amasya (1594-1657), Bilkent Üniversitesi, Tarih Bölümü, Doktora Tezi, Ankara 2001. Farklı bir değerlendirme için ayrıca bkz. Fatma Şensoy, "Muhasebe Defterlerinden Vakıfların Çok Yönlü Boyutlarını İzlemek-Bir Örnek XVIII. Yüzyıl”, Muhasebe ve Finans Tarihi Vakfi (MUFTAV), say1 7 (2014), s. 76-103.

18 Bkz. Haim Gerber, Economy and Society in an Ottoman City: Bursa, 1600-1700, The Hebrew University, Jerusalem 1988; Abraham Marcus, The Middle East on the Eve of Modernity: Aleppo in the Eighteenth Century, Columbia University Press, 1989, s. 305-311.

19 Örn. bkz. Orbay, "Structure and the Content of the Waqf Account Books" s. 3-48; ayn.yzr., "Account Books of the Imperial Waqfs (Charitable Endowments) in the Eastern Mediterranean (15th to 19th Centuries)", Accounting Historians Journal, 40, (2013), s. 31-50; ayn.yzr., "Muhasebe Defterlerine Göre 17. Yüzyıl Başlarında Üç Şerefeli Camii Vakfı", H.Ü. Türkiyat Araştırmaları, sayı 15 (2011), s. 159-165.

20 Örn. bkz. Oktay Güvemli - Batuhan Güvemli, "Osmanlı Kayıt Kültüründe Vakıf muhasebesi ve Devlet Muhasebe Sistemi”, Vakıflar Dergisi, say1 46 (2016), s. 9-10; M. Emin Durmuş - İsmail Bektaş, “Osmanlı’da Muhasebe Usulü ve Vakıf Muhasebe Kayıtları Okuma Kılavuzu”, Pesa Uluslararası Sosyal Araştırmalar Dergisi, III/2 (2017), s. 198; Şensoy, "Ebubekir Paşa”, s. 391-416.

21 Mustafa Güler, Osmanlı Devletinde Haremeyn Vakıfları (16. Ve 17. Yüzyıllar), Çamlıca Yayınları, İstanbul 2011; ayn.yzr., "The Role of the Ottoman Waqfs in the Solution of the Issue of Hebron with a Favor of Muslims", Osmanlı Medeniyeti Araştırmaları Dergisi, II/2 (Ocak 2016), s. 27-35; ayn.yzr., "Halilürrahman'ın Dura Köyünde 1863 Yılında Yaşanan Bir Asayiş Meseleri”, Filistin Araştırmaları Dergisi, Kudüs Özel Sayısı, sayı 2 (Kış 2017), s. 58-75; ayn.yzr., "Hz. İbrahim'den Bugüne Uzanan Tarihi ile Halilürrahman Vakfı Bir Filistin Köyü: Halhul”, Osmanlı Döneminde Kudüs Uluslararası Sempozyumu, İstanbul 29-30 Nisan 2017; Yasemin Akkaya, XIX. Yüzyılda Kudüs ve Çevresinde Halilü'r-Rahman Vakıflarl, Afyon Kocatepe Üniversitesi Sosyal Bilimler Enstitüsü, Yüksek Lisans Tezi, Afyon 2012; Hasan Hüseyin Güneş, "17. Yüzyılda Kudüs Halilürrahman Vakfi Görevlileri ve Vakfın İşleyişindeki Rolleri”, Journal of History Culture and Art Research, 7 (1), 647-662.

22 Örneğin bkz. Rahime Fişne, XVIII. Yüzyıl Başlarında Kudüs Surresi (Transkripsiyon ve Değerlendirme), Afyon Kocatepe Üniversitesi Sosyal Bilimler Enstitüsü Tarih Bölümü, Yüksek Lisans Tezi, Afyon 2012, s. 14; Şerife Eroğlu Memiş, Osmanlı Taşra Toplumu ve Vakıf Kurumu: Kudüs, 1703-1831, Hacettepe Üniversitesi Sosyal Bilimler Enstitüsü Tarih Bölümü, Doktora Tezi, Ankara 2016, s. 287-296; Özge Uslu, 1144 Numaralı Kudüs-i Şerif Surre Defteri (M. 1620-21/H. 1030) (Transkripsiyon-Değerlendirme), Kırklareli Üniversitesi Sosyal Bilimler Enstitüsü Tarih Bölümü, Kırklareli 2019; Ayşenur Gülen, Kudüs ahalisi surresi: Transkripsiyon ve Tahlil (1593-1623), Fatih Sultan Mehmet Üniversitesi Sosyal Bilimler Enstitüsü Tarih Bölümü, Yüksek Lisans Tezi, İstanbul 2019. 
Bu bağlamda, mevcut çalışmada Halilürrahman Vakfı'na ait müteakip muhasebe kayıtlarını incelemek suretiyle vakfın 18. yüzyıl başındaki mali durumunun tespit edilmesi amaçlanmaktadır. Böylece, Osmanlı Dönemi’nde el-Halil kenti ve vakıflarına ilişkin mevcut literatüre katkı sunmayı da amaçlayan çalışma çerçevesinde, vakfın içinde bulunduğu sosyal ve ekonomik koşullar ile ilgili bilgiler sunmaları bakımından genel olarak sosyal ve ekonomik tarih için olduğu kadar vakıflar açısından da değerli kaynaklar niteliğindeki muhasebe defterlerinde yer alan kayıtlara, bu yazının sınırları içerisinde söz konusu Halilürrahman Vakfı bağlamında başvurulacaktır.

\section{Halilürrahman Vakfı Muhasebe Defterleri}

Nispeten az bilinen ve daha az çalışılan muhasebe defterlerini daha verimli kullanmak için öncelikle kayıtların yapılarını anlamak gerekir. Vakıf gelir ve giderlerine ilişkin hesap kayıtlarındaki rakamlar bu yazıdaki incelemenin temelini oluşturmaktadır. Bu nedenle vakıf gelir ve gider rakamlarının oluşturulması amacıyla bu dokümanda uygulanan vakıf muhasebe defterlerinin yapısı kısaca tanıtılacaktır.

Sultan ve vüzerâ vakıfları gibi büyük vakıflar için mali dönem sonunda mufassal muhasebe defteri hazırlanır. Bu defterlerin boyutu vakfın gelir kaynaklarının çeşitliliği, mali işlemleri ve harcamalarının hacmi ile artar. Mali dönem ilke olarak bir senedir. Dolayısıyla muhasebede dönemsellik ilkesi mevcuttur. Ama ikinci bir prensip daha işler. Her mütevelli kendi döneminin muhasebesinden sorumludur. Bu nedenle görev değişikliklerinde süresi bir yıldan az veya aşkın muhasebeler ile karşılaşılabilir. Ana muhasebe defteri dönem içerisinde gerçekleşen tüm mali hareketlerin, gelir ve giderlerin toplulaştııılmış sonuçlarını kaydeder ${ }^{23}$.

Yıllık ana muhasebe kayıtları bazen kopyalandıkları merkeze havale edilir ve yerel tutulan hesabı çapraz kontrol etmek için başka bir müsvedde defteri hazırlanırdı. Bu hesap doğrulandıktan sonra, merkezde onaylanan ve arşivlenen nihai bir belge hazırlanırdi ${ }^{24}$. $\mathrm{Bu}$ açıklamada olduğu gibi Evkâf Haremeyn Muhasebe Defteri (EV.HMH.d) Fonu'nda 1431 numara ile kayıtlı defterin başında "müsvedde-i muhasebe-i Hazret-i Halîlürrahman der-Kudüs-i Şerîf 'an vâcib-i sene-i 1118" kaydı bulunmaktadır. Bu kayıt yıllar itibariyle birbirini takip eden iki muhasebe defterini içerir. Defterlerden ilki Muharrem 1117 (Nisan 1705) ile Zilhicce 1118 (Nisan 1707) tarihleri arasını kapsar. Bu muhasebe kaydının bir yıldan fazla bir dönemi kapsamasında vakfın mütevellisinin değişmesinin gerekçe olduğu vakfa ait gelir detayından anlaşılmaktadır. Şöyle ki, vakfın gelirleri arasında ilk kalemi eski muhasebe defterine göre sâbık mütevelli Osman Ağa'nın zimmetinde kalan meblağın gelir kaydedilmesi oluşturmuştur. Kayıt 8 varak, 15 sayfadır. İkinci muhasebe kaydı ise 1118 Mart

23 Ömer Lütfi Barkan, "Fatih İmareti", s. 300-301; Orbay, "Structure and the Content of the Waqf Account Books"s. 8.

24 Orbay, "Structure and the Content of the Waqf Account Books" s. 12. 
ayı başlangıcından (Mart 1707) ile aynı yılın Şubat sonu (Mart 1708) olmak üzere bir yıllık muhasebe dönemini kapsamaktadır. Kayıt 2 varak ve 3 sayfadan oluşmaktadır ${ }^{25}$. Defterde yer alan kayıtlar siyâkat yazı ve rakamları ile kaleme alınmıştır ${ }^{26}$. Gelir ve gider kaydının muhasebesi merdiven yöntemi kullanılarak yapılmıştır ${ }^{27}$.

$\mathrm{Bu}$ muhasebe kayıtlarından ilki nahiyelerdeki vakıf kâtiplerinin hesapları esas alınarak hazırlanmıştır. Zirâ vakfın; el-Halil, Kudüs, Gazze, Remle, Nablus, Halep, Şam ve Mısır'daki nâhiyelerde kayıtlı müstegallât ve musakkafâtları bulunmakta idi. Bu muhasebe defteri vakfın mütevellisi el-Hac Hasan Ağa döneminde Dârüssaade Ağası Süleyman Ağa'ya sunulmuştur. Vakıf gelir ve giderlerini tafsilatlı bir şekilde sunan muhasebe defterinde vakfın gelir, gider ve vakıf köylerindeki re‘âyâ ile kiracılarda kalan bâkî hesaplar kaydedilmiş, Kudüs Kazası Kadısı Mustafa'nın mührü ile denkleştirilmiştir.

Defterde yer alan muhasebe kayıtlarından ikincisi ise, vakfın fodula ${ }^{28}$ defteri esas alınarak hazırlanmış ve vakfın mütevellisine sunulmuştur. Vakfın gelirleri, giderleri ile vakıf köylerindeki re‘âyâ ile kiracılarda kalan bâkî hesaplar kaydedilmiş, vakıf kâtibinin mührü ile hesaplar denkleştirilmiştir. Bununla birlikte her iki kayıtta da önceki yıldan vakıf re‘âyâsı ile kiracılar elinde kalan gelirler de vakıf bütçesine önemli bir diğer gelir kaynağı olmuştur.

25 BOA, EV.HMH.d., nr. 1431.

26 Oktay Güvemli, Muhasebe Tarihi, Avcılol Basım Yayım, İstanbul 1995, s. 1-91. Siyakat yazısı hakkında detaylı incelemeler için bkz. Said Öztürk, Osmanlı Arşiv Belgelerinde Siyakat Yazısı ve Tarihi Gelişimi, OSAV, İstanbul 1996, s. 19; Fatma Şensoy - Oktay Güvemli, "The State Accounting Doctrine Book of The Middle East In The XIV Century: Risale-i Felekiyye-Kitab-us Siyakat And Its Place in Accounting Culture", The British Accounting Review, say1 47 (2015), s. 159-176.

27 Batuhan Güvemli - Özcan Unutkan, "The Practice of Merdiban Method in State Accountancy According to Ottoman Documents", Muhasebe ve Finans Tarihi Araştırmaları Dergisi, say1 11 (Temmuz 2016), s. 71-110.

28 Singer'a göre, fodula, un, tuz ve sudan yapılan sade somunlar için kullanılmıştır. Fırından çıktıktan sonraki her bir fodulanın standart ağırlığ 90 dirhem olmalıydı. Amy Singer, Osmanlı'da Hayırseverlik - Kudüs 'te Bir Haseki Sultan İmareti, çev. Dilek Şendil, Tarih Vakfı Yurt Yayınları, İstanbul 2004, s. 69. 1 dirhemin yaklaşık 3 gram olduğu kabul edilirse bir somunun hamur ağırlığı yaklaşık 270 gr. olmaktadır. Halil İnalcık, "Weights and Measures", An Economic and Social History of the Ottoman Empire, der. H. İnalc1k ve D. Quataert, c. I, Cambridge University Press, Cambridge 1997, s. 988. Öte yandan Emecen, Fudûla/Fodula/Fodla gibi değişik adlandırma şekillerine yer verdiği ekmekleri, daha ziyâde imaretlerde, Osmanlı saray mutfağında, İstanbul'daki diğer bazı saraylarda ve yeniçerilere ait fırınlarda pişirilen ve bir kısım görevlilere maaşları ile birlikte sepet içinde istihkâkına göre dağıtılan pide şeklinde yassı ekmek için kullanılmış bir tâbir olarak tanımlamıştır. Feridun Emecen, "Fodula”, DİA, c. XIII, İstanbul 1996, s. 167-170. 
Tablo 1

Halilürrahman Vakfı Muhasebe Kayıtlarının Yapıları

\begin{tabular}{|c|c|}
\hline I. Muhasebe Kaydı & II. Muhasebe Kaydı \\
\hline $\begin{array}{l}\text { 'Ani’l-mevcûdât der zimmet-i mütevelli-i sâbık } \\
\text { (Anbar Mevcudu) }\end{array}$ & $\begin{array}{l}\text { 'An mevcûd-ı anbar-ı kerîm berevât-ı surre-i ... Osman } \\
\text { Ağa mütevelli-i sâbık kabz kerde } \\
\text { (Anbar Mevcudu) }\end{array}$ \\
\hline $\begin{array}{l}\text { 'An mahsûlat ma'a emvâl-i müteferrika } \\
\text { (Gelirler) } \\
\text {-'An Nâhiye-i Medînetü'l-Halilürrahman } \\
\text { - 'An Nâhiye-i Medînetü'l-Kudüs-i Şerîf } \\
\text { - 'An Nâhiye-i Sâhil-i Gazze } \\
\text {-'An Nâhiye-i Sâhil-i Ramle } \\
\text { - 'An mahsûl-ı Nâhiye-i Nablus ve Ben-i Sâ'b } \\
\text { - 'An emvâl-i müteferrika Nâhiye-i Haleb ve } \\
\text { Nâhiyetü'ş-Şam ve Nâhiye-i Misır }\end{array}$ & 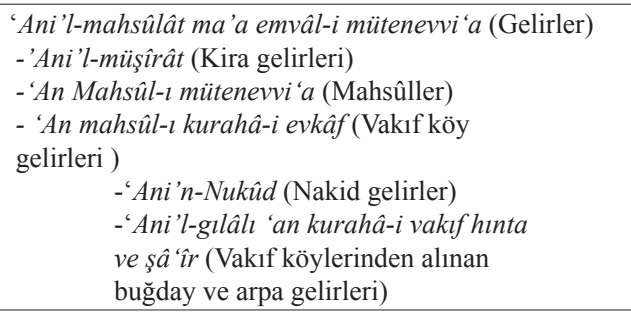 \\
\hline $\begin{array}{l}\text { Vaz'-ı Mâl (Vakfın Giderleri) } \\
\text { - 'Ani'l-mevâcib } \\
\text { - El-vezâif (Görevli ücretleri) } \\
\text { - Anbar Masrafları } \\
\text { - Tenvir Masrafları (Aydınlatma) } \\
\text { - el-İhrâcât Masraflarl (Harcamalar) } \\
\text { - Ta'âmiyye-i Mütevelli (Mütevellinin yemek } \\
\text { masrafi) }\end{array}$ & $\begin{array}{l}\text { Vuzi ‘a min zâlik (Vakfin Giderleri) } \\
\text { - El-vazâif (Görevli ücretleri) } \\
\text { - Vâcibât (Masraflar) } \\
\text {-Harc-ı matbah (Mutfak giderleri) } \\
\text {-Muhasebât (Hesap işleri) } \\
\text {-Meremmet (Tamir) }\end{array}$ \\
\hline$E l-B a ̂ k \hat{\imath}($ Kalan$)$ & El-Bâkî (Kalan) \\
\hline
\end{tabular}

Tablo 1'de görüldüğü gibi, 'ani'l-mevcûdât der zimmet-i mütevelli-i sâbık'1n kayd1, "geçen yılın fazlası ile birlikte tam yılın geliri icâre-i muhâsebe-i sene-i mâziyye'ye eşittir, önceki yılın fazlası "artı” 'an mahsûlât ma'a emvâl-i müteferrika gelir. Bir önceki yılın fazlası olan 'ani'l-mevcûdât der zimmet-i mütevelli-i sâbık başlığı altındaki rakam, aynı zamanda ödenmemiş hesap yılının sonunda tahsil edilmemiş kalan gelirin toplamına eşittir ve kâtipler nakit fazlası anlamına gelen son bâkî (artı) şeklinde kaydederler. Diğer bir deyişle, bir önceki yıldan kalan tahsil edilmemiş gelirler ve bir önceki yılın hesap defterinin sonunda son bâkî kaydı altında kaydedilen önceki yılın nakit fazlası, cari yıl hesabında "bir önceki yılın fazlası"nın girişini oluşturmaktadır.

O zaman bir önceki yıla göre artığı temsil eden rakam, cari yıl gelirleri arasında sayılsa bile tamamen nakit ve harcanabilir gelir anlamına gelmez. Toplanmamış gelirleri içerir ve vakıf cari yıl içinde bu borçları tamamen veya kısmen tahsil edebilir veya etmeyebilir. Bu girişin nakit kısmı, önceki yılın son bâkî girişinde ifade edilen rakama eşittir.

\section{Vakfın Gelirleri}

Muhasebe kayıtlarındaki ilk kayıt vakfın gelirlerini içermektedir. Tablo 2 ve 5'te görüleceği üzere, vakfın toplam geliri 'Ani'l-mahsûlât ma'a emvâl-i mütenevvia' başlığ1 altında kaydedilen cari yılda beklenen gelir ile bir önceki yıldan vakfın eski mütevellisinde kalan 'Ani'l-mevcûdât der zimmet-i mütevelli-i sâbık başlığı altında kaydedilen anbar 
mevcudu olmak üzere iki kısımdan oluşmaktadır. Eski mütevellinin zimmetinde kalan gelir cari yılda tek kalemde ve detay belirtilmeden kaydedilmiştir. Buna karşılık vakfın cari yıldaki gelirleri 'ani'n-nukûd ve 'ani'l-gılâlât başlıkları altında kaydedilmiştir. Burada kaydedilen 'ani'n-nukûd, vakfın gelirleri arasında nakid olarak tahsil ve çeşitli masrafları karşılamak üzere sarf edilen paralara ait kasa hesaplarıdır. 'Ani'l-gılâlât adı altında ve vakıf köylerin mahsulünden bir hisse şeklinde aynî olarak tahsil edilen gelirlerin miktar ve çeşitleri ile sarfı şekillerine ait bulunan anbar hesaplarıdır ${ }^{29}$.

\section{a. Vakfın I. Muhasebe Kaydında Kayıtlı Gelirleri}

Vakfın 1705-1707 yılları arasını kapsayan I. muhasebe kaydında kayıtlı gelirlerin dağılımı şöyledir:

Tablo 2

Halilürrahman Vakfı'nın I. Muhasebe Kaydına Göre Gelirleri (para)

\begin{tabular}{|l|c|c|c|c|}
\hline Gelirler & Nukûd & Gllâlât & \% & Toplam \\
\hline $\begin{array}{l}\text { 'Ani'l-mevcûdât der zimmet-i mütevelli-i sâbık Lala Osman Ağa } \\
\text { (Eski mütevellinin zimmetinden gelen mevcut) }\end{array}$ & 115.974 & - & $\mathbf{1 3 , 3 1}$ & $\mathbf{1 1 5 . 9 7 4}$ \\
\hline 'An Nâhiye-i Medîneti Halilürrahman & 78.557 & 302.054 & $\mathbf{4 1 , 6 0}$ & 362.611 \\
\hline 'An Nâhiye-i Medîneti Kudüs-i Şerîf & 12.235 & 77.130 & $\mathbf{1 0 , 2 5}$ & 89.365 \\
\hline 'An Nahiye-i Sahil-i Gazze ve Beni Süheyle & 9.600 & 72.747 & $\mathbf{9 , 4 5}$ & 82.347 \\
\hline 'An Nahiye-i sahili er-Remle & 3.180 & 35.130 & $\mathbf{4 , 4 0}$ & 38.310 \\
\hline 'An mahsûl-ı Nahiye-i Nablus ve Beni Sa'b & & - & $\mathbf{6 , 8 8}$ & 60.000 \\
\hline $\begin{array}{l}\text { Emvâl-i müteferrika Nahiye-i Haleb ve Nahiyetü'ş-Şam ve Nahiye-i } \\
\text { Misır Müsemmat ve gayri zalik }\end{array}$ & & - & $\mathbf{1 4 , 1 1}$ & 123.000 \\
\hline Toplam & & $\mathbf{1 0 0}$ & $\mathbf{8 7 1 . 6 0 7}$ \\
\hline
\end{tabular}

Halilürrahman Vakfi'na ait yukarıda Tablo 2'de sunulan muhasebe kaydında yer alan gelirlerin dağılımına bakıldığında \%41,60 oranı ile en büyük kısmı, vakfın el-Halil kentinde bulunan musakkafât ve müstegallâtından alınan nukûd ve gllâlât gelirlerinin oluşturduğu görülmektedir. Vakfin nukûd gelirleri 28 kalemde kaydedilmişken, gllâlât olarak vakfin elHalil nahiyesinde bulunan ve aşağıda Tablo 4'te sunulan Halhol, Duri, Edna, Beni Naim, Leta, Gabad, Harsa köylerinin mahsulleri yine 28 kalemde verilmiştir. Köylerde buğday, arpa, pirinç, susam başlıca mahsuller olarak yer almaktayken âdet-i ăgnam şeklinde kaydedilen gelirler ise kuzu adedine göre belirlenen ve tahsil edilen gelirlerdi. 'Ardu'ş-Şağa mezraasının gelirleri ise tek bir kalemde el-Halil nahiyesi gelirlerine eklenmiştir.

Ancak defterde yer alan rakamların yazımında bazı yanlışlıklar yapıldığg da tespit edilmiştir. Şöyle ki Tablo 3'te de görüleceği üzere defterde 'ani- 'n-nukûd başlı̆̆ı 78.557 para olarak kaydedilmişken, kaydedilen rakamlar tek tek toplandığında bu rakam 79.264 olmaktadır. 'Ani'l-gılâlât başlığı ise 302.054 para olarak kaydedilmişken, aşağıda Tablo 5'in el-Halil nâhiyesi köyleri kısmında görüleceği üzere el-Halil nâhiyesi köylerine ait mahsul

29 Barkan, "Fatih İmareti", s. 301-302. 
rakamları tek tek toplandığında bu rakam 288.552 olmaktadır. Bu iki rakam toplandığında ise el-Halil nâhiyesi geliri toplamda 367.816 para olarak tespit edilmiştir ${ }^{30}$. Benzer bir probleme diğer nâhiye hesaplarında rastlanılmamıştır. Çalışma çerçevesinde yer verilen Tablo ve hesaplamalarda defterde yer alan rakamlar esas alınarak, aynen yazılmıştır. Zira yıl sonu hesapları bu rakamlarla tutarlıdır.

Tablo 3

el-Halil Nâhiyesi'nden 'ani'n-nukûd başlığı altında tahsil edilen gelirler

\begin{tabular}{|c|c|c|c|}
\hline \multirow{28}{*}{ 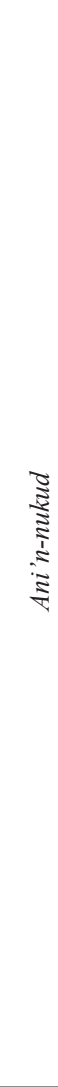 } & 1 & 'An-mahsûl-ı nuzûr-ı sanduk-ı şerîf câbi & Hâlî \\
\hline & 2 & 'An-mahsûl-ı hammam-ı vakf-ı şerif be-muceb-i icâre-i sâbıka defter-i nâib-i nâhiye. & 13.500 \\
\hline & 3 & 'An-mahsûl-ı kaban der-Medine-i Seyyidüna el-Halil aleyhisselam. & 7.200 \\
\hline & 4 & 'An-mahsûl-ı bostan-ı havâle-i mürtezika-i vakıf. & 720 \\
\hline & 5 & 'An-mahsûl-ı ücreti beyti Şeyh Ali el-Mağribi. & 60 \\
\hline & 6 & 'An-mahsûl-ı han-ı Ahmed havale-i mürtezika. & 540 \\
\hline & 7 & 'An-mahsûl-ı Dâru'l-muttalib havâle-i mürtezika. & 240 \\
\hline & 8 & 'An-mahsûl-ı dâru't-tavâsi ve dâru’l-Halil. & 300 \\
\hline & 9 & 'An-mahsûl-ı hazîne-i Cizye-i Yahud havâle-i..... medine. & 4.380 \\
\hline & 10 & 'An-mahsûl-ı mezra'a-i arzı iltizam havâle-i mürtezika & 19.630 \\
\hline & 11 & 'An-mahsûl-ı mezra'a-i arzı Karun havâle-i mürtezika. & 3.550 \\
\hline & 12 & 'An-mahsûl-ı dâru’l-bevvâb havâle-i mürtezika. & 60 \\
\hline & 13 & 'An-mahsûl-ı hikri arzı Banya havâle-i mürtezika. & 120 \\
\hline & 14 & 'An-mahsûl-ı hakure-i necmi el-Kadı havâle-i mürtezika. & 30 \\
\hline & 15 & 'An-mahsûl-ı Hakure-i ebi'l-beka havâle-i mürtezika. & 30 \\
\hline & 16 & 'An-mahsûl-ı ücreti Beytü'l-hammam havâle-i mürtezika. & 30 \\
\hline & 17 & 'An-mahsûl-ı sathı Mâristan havâle-i mürtezika. & 60 \\
\hline & 18 & 'An-mahsûl-ı hikr-i Kürum erbain havâle-i mürtezika. & 260 \\
\hline & 19 & ‘An-mahsûl-ı arzı hârice havâle-i mürtezika. & 60 \\
\hline & 20 & 'An-mahsûl-ı arzı Celal havâle-i mürtezika. & 240 \\
\hline & 21 & 'An-mahsûl-ı arzı Beni Selim havâle-i mürtezika. & 3.864 \\
\hline & 22 & 'An-mahsûl-ı arzı Murad en-Niac havâle-i mürtezika. & 120 \\
\hline & 23 & 'An-mahsûl-ı dâr-ı ve Kerem Evladı Bedir havâle-i mürtezika. & 600 \\
\hline & 24 & 'An-mahsûl-ı nakdi mâli’s-sûk sene 1118. & 5.560 \\
\hline & 25 & 'An-mahsûl-ı mezbûr kura el-vakıf. & 90 \\
\hline & 26 & 'An-mahsûl-ı maktû-ı karye-i Mecdel tahsil. & 4500 \\
\hline & 27 & 'An-mahsûl-ı ma'adini..... hazîne-i rûyi 3290 kıyye. & 13.180 \\
\hline & 28 & 'An-mahsûl-l vakfi..... & 340 \\
\hline \multicolumn{3}{|c|}{ Toplam } & 78.557 \\
\hline
\end{tabular}

Yukarıda Tablo 3'te sunulan ve el-Halil nâhiyesinin 'ani'n-nukûd başlığg altında kayıtlı kentsel gelirlerini vakfin çeşitli mevkilerde bulunan musakkafât cinsi hamam, kaban, bostan, dâr (ev), han gibi akarlarının gelirleri ile mezraa, hakûre (sebze bahçesi), kürum (üzüm bağı) gibi müstegallât nev’inden akarların gelirleri oluşturmuştur.

30 Ayrica bkz. Ek. 
Defterde, el-Halil nâhiyesi gelirlerini \%14,11 oranı ile Halep, Şam, Mısır ve diğer bazı yerlerden gelen ve toplu bir şekilde 6 kalemde kaydedilen gelirler oluşturmuştur. Tablo 2'de görülen ve vakfın cari yıla ait üçüncü gelir kalemini vakfın eski mütevellisi zimmetinden gelen ve \%13,31'lik bir orana sahip olan gelirler oluşturmuştur. Vakfın dördüncü gelir kalemini \%10,25'lik bir oran ile Kudüs nahiyesi gelirleri oluşturmuştur. Çoğunlukla kira gelirlerinden, mahsul cinsinden oluşan ve 16 kalemde kaydedilen gelirleri; vakfın Ramallah, Kâdiriyye, Zekeriyye köyleri mahsullerinin 11 kalemde kaydedildiği gelirler takip etmiştir. Beşinci sırada yer alan Gazze Sahili ve Beni Süheyle nahiyesi gelirleri ise vakıf gelirleri arasında \%9,45 oranına sahiptir. Cenin, es-Satur, el-Müsemmiye, Gıyab, el-Vemad es-Suğra köylerinin mahsulleri 23 kalemde kaydedilmiştir. Vakıf gelirleri arasında \%6,88 oran ile altıncı sırada yer alan Nablus ve Beni Sa'ab nahiyelerinden gelen mahsul gelirleri ile kira gelirleri tek bir kalemde, detay verilmeden kaydedilmiştir. Vakıf gelirleri arasında \%4,40 oran ile son sırada yer alan Remle sahili nâhiyesi gelirleri arasında Letron, Beyt-i Nevbâ, Beyt-i Benala köylerine ait mahsul gelirleri 23 kalemde kaydedilmiştir.

Örneğin, vakfın 'ani'n-nukûd başlığı altında kaydedilen 'an nâhiye-i medîneti Kudüs-i Şerîf gelirleri ise şöyledir:

Tablo 4

Kudüs Nâhiyesi’nden 'ani’n-nukûd başlığı altında tahsil edilen gelirler

'An-Nâhiye-i Medineti'l-Kudüs eş-Şerif be-mûceb-i defter-i kâtib en-nâhiye el-mezbûre ber-vech-i faslı 'an-vâcib sene 1117.

\begin{tabular}{|c|c|c|c|}
\hline \multirow{16}{*}{ 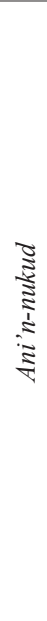 } & 1 & 'An-mahsûl-ı icâr-ı sabun be-mûcebi Defter-i Nâib en-Nâhiye el-mezbûre. & 1.080 \\
\hline & 2 & 'An-mahsûl-ı icâre-i 12 kırat tahûn der-Kudüs-i Şerif. & 1.800 \\
\hline & 3 & 'An-mahsûl-ı icâre-i 12 kırat firın der-Kudüs-i Şerif. & 10.580 \\
\hline & 4 & 'An mahsûl-ı 3 kırat Bumi Aba der-yed-i Seyyid Muhibbiddin. & 180 \\
\hline & 5 & 'An-mahsûl-ı icâre 65 kırat karye-i Surmahi. & 1.800 \\
\hline & 6 & 'An-mahsâl-ı maktû 8 kırat karye-i Elmalı. & 2.100 \\
\hline & 7 & 'An-mahsûl-ı 12 kırat karye-i Balı der-Kudüs-i Şerif. & 90 \\
\hline & 8 & 'An-mahsûl-l fì yed-i Badis Baba ... bin Mehmed İsa. & 360 \\
\hline & 9 & 'An-mahsûl-ı fì yed-i merhum Abdulkadir el-Hariri. & 225 \\
\hline & 10 & 'An-mahsûl-ı ... Mehmed ...der Kudüs-i Şerif & 150 \\
\hline & 11 & 'An-mahsûl-ı hayri .... El-amud. & 30 \\
\hline & 12 & 'An-mahsûl-ı kürüm Nassar der-yed-i karye-i Lefta. & 300 \\
\hline & 13 & 'An-mahsûl-l 13 kırat karye-i Sülük..... & 2.400 \\
\hline & 14 & 'An-mahsûl-ı kürum-ı karye-i Hilal arz-ı beyti .... & 720 \\
\hline & 15 & 'An-mahsûl-ı 12 kırat Alekar der-Kudüs-i şerif. & 120 \\
\hline & 16 & 'An-mahsûl-ı arzı Zekeriyâ havâle-i mürtezika. & 900 \\
\hline \multicolumn{3}{|r|}{ ( } & 12.235 \\
\hline
\end{tabular}

Yukarıda tablo halinde sunulan gelirlere bakıldığında değirmen, firın gibi musakkafât cinsinden gelirlerin yanı sıra çeşitli ölçülerde değişen müstegallâta ait kiralar da kaydedilmiştir. 'Ani'n-nukûd gelirleri aynı zamanda vakfın kentsel gelirleridir. 
Vakfın kentsel gelirlerinin yanı sıra vakıf köy ve mezraalardan elde edilen tarımsal ürünler vakfın temel gelir kaynağını oluşturmuştur. Aşağıda Tablo 4'te ise vakıf gelirinin bu büyük kısmını oluşturan vakıf köyler ve mezraalar (tarıma elverişli araziler) başlıkları altında mahsul (gllâlât) gelirleri sunulmuştur.

\begin{tabular}{|c|c|c|c|}
\hline \multicolumn{4}{|c|}{$\begin{array}{c}\text { Tablo } 5 \\
\text { I. Muhasebe Kaydına Göre Vakfin Köy ve Mezraa Gelirleri (para) }\end{array}$} \\
\hline Nâhiye Adı & Köy ve/veya Mezraalar & $\begin{array}{c}\text { Gılâlât } \\
\text { (Gelirler) }\end{array}$ & Toplam \\
\hline el-Halîl & $\begin{array}{l}\text { 1.Karye-i Halhol } \\
\text { 2.Karye-i Duri } \\
\text { 3.Karye-i Edna } \\
\text { 4. karye-i Beninaim } \\
\text { 5.Karye-i Leta } \\
\text { 6.Karye-i Gabad } \\
\text { 7.Karye-i Harsa } \\
\text { 8.Mezra'a-i Ardu'ş-Şağa }\end{array}$ & $\begin{array}{r}83.810 \\
62.806 \\
53.600 \\
18.538 \\
36.560 \\
12.000 \\
12.900 \\
3.840 \\
\end{array}$ & 302.054 \\
\hline \multirow[b]{2}{*}{ Kudüs-i Şerîf } & $\begin{array}{l}\text { 1.Karye-i el-Kadiriye } \\
\text { 2.Karye-i Ramallah } \\
\text { 3.Karye-i Zekeriyye }\end{array}$ & $\begin{array}{c}4.740 \\
38.180 \\
21.380 \\
\end{array}$ & \multirow[b]{2}{*}{77.130} \\
\hline & $\begin{array}{l}\text { Nahiye-i Nebiyyi veled } \\
\text { 1.Karye-i Düser Gassane } \\
\text { 2. karye-i Abus } \\
\text { 3. Karye-i Arderi (2 kırat) } \\
\text { 4.Karye-i Amadi (4 kırat) } \\
\text { 5. Muratreya }\end{array}$ & 10.040 & \\
\hline $\begin{array}{l}\text { Nahiye-i Sahil-i Gazze } \\
\text { ve Beni Süheyle }\end{array}$ & $\begin{array}{l}\text { 1. Karye-i Cenin } \\
\text { 2.Karye-i Essatur } \\
\text { 3.Karye-i el-Müsemmiye } \\
\text { 4.Karye-i Glyab } \\
\text { 5.Karye-i el-Vemad es-Suğra }\end{array}$ & $\begin{array}{c}11.630 \\
24.060 \\
27.287 \\
6.400 \\
3.360 \\
\end{array}$ & 82.347 \\
\hline Nahiye-i sahili er-Remle & $\begin{array}{l}\text { 1.karye-i Letron } \\
\text { 2.karye-i Beyti nevba-I } \\
\text { 3.Beyti Banala }\end{array}$ & $\begin{array}{c}25.600 \\
11.400 \\
8130\end{array}$ & 35.130 \\
\hline $\begin{array}{l}\text { Nahiye-i Nablus ve Beni } \\
\text { Sa'b }\end{array}$ & 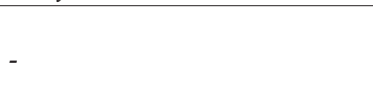 & 60.000 & 60.000 \\
\hline $\begin{array}{l}\text { Nahiye-i Haleb ve } \\
\text { Nahiyetü'ş-Şam } \\
\text { ve Nahiye-i Misır } \\
\text { Müsemmat ve gayri } \\
\text { zalik }\end{array}$ & $\begin{array}{l}\text { 1.Nâhiye-i Haleb } \\
\text { 2.Ummal-ı Dımışkı 's-Şam } 1117 \\
\text { 3.Ummal-ı an-vâcib-i sene } 1116 \\
\text { 4.An-vâcib-i sene } 1117 \\
\text { 5.Ummal-ı Sultan Gavri } \\
\text { 6.Ummal-ı Lererona }\end{array}$ & $\begin{array}{c}22.500 \\
31.500 \\
34.500 \\
34.500 \\
18.000 \\
4.500 \\
\end{array}$ & 123.000 \\
\hline \multicolumn{3}{|l|}{ Toplam } & 755.633 \\
\hline
\end{tabular}

Burada tablo halinde sunulan rakamları biraz daha detaylandıracak olursak, örneğin elHalil nâhiyesindeki köylerin gelirlerinin detayları şöyledir: 


\begin{tabular}{|c|c|c|c|c|}
\hline $\begin{array}{l}\text { 'An-mahsûl-ı karye-i } \\
83.810 \text { para. }\end{array}$ & alhol ber-vechi fas & huzuri'l-mütevelli & mucebi defter-i & -i nahiye-i mezbure \\
\hline Hinta keyl 144 para & Şa'îr keyl 144 & Dibs 262 vukiyye & Addad-ı ă̆nam & $\begin{array}{c}\text { Maadin-i karye- } i \\
\text { mezbure }\end{array}$ \\
\hline Baha 49.680 para & Baha 24.840 para & Baha 3.150 para & 1.940 para & 4.200 para \\
\hline
\end{tabular}

'An-mahsûl-ı karye-i Duri ber-vechi faslı bi huzurl el-mütevelli ve muceb-i defter-i kâtib-i nahiye-i mezbure. 62.806 para

\begin{tabular}{|l|c|c|c|c|}
\hline Hinta keyl 124 para & Şa't̂r keyl 124 & Dibs 125 vukiyye & Addad-l ağnam & $\begin{array}{c}\text { Maadin-i karye- } i \\
\text { mezbure. }\end{array}$ \\
\hline Baha 38.680 para & Baha 17.441 para & Baha 1.506 para & 1.780 para & 2.400 para \\
\hline
\end{tabular}

'An-mahsûl-ı karye-i Ednâ-i vâcib sene 1117 bi-huzuri'l-mütevelli ve defter-i kâtib-i nahiye-i mezbure. 53.600 para

\begin{tabular}{|c|c|c|c|c|}
\hline Hinta keyl 100 para & Şa'îr keyl 100 & $\begin{array}{c}\text { Ruğan-l zeyt } 80 \\
\text { klyye }\end{array}$ & $\begin{array}{c}\text { Maadin-i karye- } i \\
\text { mezbûre }\end{array}$ & \\
\hline Baha 32.000 para & Baha 16.000 para & Baha 3.200 para & 2.400 para & \\
\hline
\end{tabular}
para

\begin{tabular}{|l|c|c|c|c|}
\hline Hinta keyl 55 para & Şa'îr keyl 55 & Dibs 96 kiyye & $\begin{array}{c}\text { Addad-l ağnam-l } \\
\text { karye }\end{array}$ & $\begin{array}{c}\text { Maadin-i karye- } i \\
\text { mezbure. }\end{array}$ \\
\hline Baha 8.800 para & Baha 4.400 para & Baha 1.158 para & 1.780 para & 2.400 para \\
\hline
\end{tabular}

'An-mahsûl-ı karye-i Leta-i vâcib sene 1117 bi-huzur-ı mütevelli ve be-muceb-i defter-i kâtib-i nahiye-i 36.560 para

\begin{tabular}{|l|c|c|c|c|}
\hline Hinta keyl 70 para & Şa'̂̀r keyl 70 & $\begin{array}{c}\text { Addad-l ağnam-l } \\
\text { karye-i mezbure }\end{array}$ & $\begin{array}{c}\text { Maadin-i karye- } i \\
\text { mezbure }\end{array}$ & \\
\hline Baha 22.400 para & Baha 11.200 para & 1.560 para & 2.400 para &
\end{tabular}

'An-mahsûl-ı karye-i Gabad be-muceb-i defer-i kâtib

12.000 para

\begin{tabular}{|l|c|}
\hline Hinta keyl 55 para & Şa'îr keyl 55 \\
\hline Baha 800 para & Baha 4.000 para \\
\hline
\end{tabular}

'An-mahsûl-l karye-i Harsa be-muceb-i defer-i kâtib-i nâhiye 12.900 para

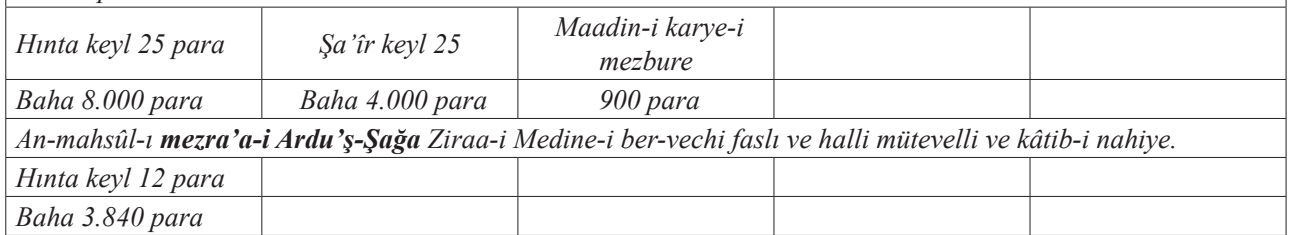

Hem kayıt usulüne hem de köylerden alınan mahsullere ilişkin bilgiler sunan yukarıdaki el-Halil nâhiyesi köy ve mezraa gelirlerinin toplamı 302.054 paradır. Bu da vakfa en fazla gelir sağlayan kalemdir. El-Halil nâhiyesi köylerinden buğday (hınta), arpa (şâ ‘ir), köyde mevcut kuzulardan alınan gelir (âdet-i ăgnâm), zeytinyağı (ruğan-l zeyt), madenler (madâin) gibi mahsuller vakfın cari yıldaki gelirleri olarak kaydedilmiştir. Halilürrahman Vakfı'na ait H.1117-18/M. 1805-1807 tarihli muhasebe defteri esas alınarak sunulan gelir tabloları vakfın temel gelir kaynağının vakıf köylerden toplanan tarımsal ürünler olduğunu göstermiştir. Bununla birlikte vakfın kentsel gelirlerini oluşturan han, hamam ve değirmenlere ait kira gelirleri de yine vakıf bütçesi açısından önemli gelir kaynaklarıdır. 


\section{b. Vakfın II. Muhasebe Kaydında Kayıtlı Gelirleri}

Çalışmanın bu kısmında defterde kayıtlı Mart 1707-1708 cari yılına ait II. muhasebe kaydındaki gelirler incelenecektir. Buna göre vakfın ilgili yıldaki gelir dağılımı şöyledir:

Tablo 6

Halilürrahman Vakfı'nın II. Muhasebe Kaydına Göre Gelirleri (para)

\begin{tabular}{|c|c|c|c|c|c|c|c|}
\hline No & \multicolumn{5}{|l|}{ Gelirler } & $\%$ & Toplam \\
\hline 1 & \multicolumn{5}{|c|}{ 'An mevcûd-ı anbar-ı kerîm (Anbar mevcudu) } & 12,56 & 115.974 \\
\hline \multirow{5}{*}{2} & \multicolumn{5}{|c|}{ 'Ani'l-mahsûlât ma'a emvâl-i mütenevvi 'a (Gelirler) } & \multirow{5}{*}{87,44} & \multirow{5}{*}{807.406} \\
\hline & a. 'Ani'l-müşî́râ & Kira gelirleri) & & 17,71 & 163.572 & & \\
\hline & b. 'An Mahsûl-l & nütenevvi 'a (Mahsûller) & & 15,05 & 139.000 & & \\
\hline & \multirow{2}{*}{$\begin{array}{l}\text { c. 'An mahsîl-- } \\
\text { kurahâ-i evkâf } \\
\text { (Vakıf köy } \\
\text { gelirleri ) }\end{array}$} & \begin{tabular}{|l} 
'Ani'n-Nukûd \\
(Nakid gelirler)
\end{tabular} & 132.794 & \multirow[b]{2}{*}{54,68} & \multirow[b]{2}{*}{504.834} & & \\
\hline & & $\begin{array}{l}\text { 'Ani'l-gılâlı 'an kurahâ-i } \\
\text { vakıf hinta ve şâ 'îr } \\
\text { (Vakıf köylerinden alınan } \\
\text { buğday ve arpa gelirleri) }\end{array}$ & 372.040 & & & & \\
\hline \multicolumn{6}{|l|}{ Toplar } & 100 & 923.380 \\
\hline
\end{tabular}

Tablo 6'ya göre cari yıl içinde beklenen gelir, gelirlerin \%87,44'ünü oluştururken, önceki yıla ait fazla vakıf gelirlerinin\%12,56'sını kapsamaktadır. Bu \%87,44'lük gelirler arasında en büyük payı vakıf köylerden nukûd ve gelir olarak alınan mahsuller ve kira gelirleri oluşturmuştur. Bu kayıtta da vakfın esas gelir kaynağını oluşturan tarımsal üretim \%54,68'lik bir orana sahiptir. Gelirlerin bir kısmı $(\% 15,05)$, bahçe ve değirmen kirası $(\% 17,71)$ da toplam gelir rakamında önemlidir. Tarım ürünlerinden elde edilen gelirler gllâlât başlığı altında hesap defterlerine kaydedilmiştir. Önceki yıla ait fazlalık ise eski mütevelli Osman Ağa'nın zimmetinden alınarak vakfın anbar mevcuduna kaydedilen ve vakıf bütçesinin yaklaşık \%12,56'sını kapsayan gelirlerdir. Öte yandan, defterde kayıtlı I. muhasebe kaydında köylerin isimlerinden ve gelir kalemlerinden detaylı bir şekilde bahsedilirken, bu detaylara II. kayıtta yer verilmemiştir. Örneğin vakfın köy gelirleri arpa ve buğday gelirleri olarak iki kalemde toplu bir şekilde yazılmıştır. Cari yıla ait bütün gelir kaynakları ise 22 kalemde yazılmıştır. Bu gelir kalemleri şöyledir: 
Tablo 7

Halilürrahman Vakfı'nın II. Muhasebe Kaydına Göre Gelir Detayları (para)

\begin{tabular}{|c|c|c|c|c|}
\hline \multicolumn{4}{|c|}{ 'Ani'l-mahsulât ma'a emval-i mütenevvia' } & 807.406 \\
\hline \multirow{5}{*}{$\begin{array}{l}\text { 'Ani’l-müşîrât } \\
\text { fi't-târîh el-mezbûr }\end{array}$} & 1 & $\begin{array}{l}\text { 'An-mahsûl-l senedât icarât-ı hammam ve dekâkin } \\
\text { ve icâre-i sâire der-yed-i müste'cirîn } \\
\text { 'an vâcib sene } 1118 \text { fi sene }\end{array}$ & 78.557 & \multirow{5}{*}{163.572} \\
\hline & 2 & $\begin{array}{l}\text { 'An-mahsîl-ı icarât ve binâ-yı Kudüs-i şerif ve } \\
\text { maktû 'at ve dekâkin ve icârât-l sâire. } \\
\text { Fi't-târîh mezbûr. Fî sene }\end{array}$ & 12.235 & \\
\hline & 3 & $\begin{array}{l}\text { 'An-mahsûl-ı icâre-i dekâkin ve tahûn der yed-i } \\
\text { müste'cirîn. } \\
\text { Fi't-târîh mezbûr ... }\end{array}$ & 9.600 & \\
\hline & 4 & $\begin{array}{l}\text { 'An-mahsûl-ı icârât-ı Halîl, Nablisi ... ve müste'cirîn } \\
\text { Fi't-târîh mezbûr. Fî sene }\end{array}$ & 60.000 & \\
\hline & 5 & $\begin{array}{l}\text { 'An-mahsûl-ı icâre-i tahun ve maktû'at. } \\
\text { Der-yed-i müste'cirîn. } \\
\text { Fi't-târîh-i mezbûr. Fî sene. }\end{array}$ & 3.180 & \\
\hline \multirow{3}{*}{$\begin{array}{l}\text { 'An-mahsûl-ı } \\
\text { mütenevvi'a-i mezkûrîn. }\end{array}$} & 1 & $\begin{array}{l}\text { 'An-mahsûl-ı mâl-ı Halîl der-yed-i câbi-i Vakf-l } \\
\text { Sultan Gavri. }\end{array}$ & 30.500 & \multirow{3}{*}{139.000} \\
\hline & 2 & $\begin{array}{l}\text { 'An-mahsûl-ı icârât-ı mâl der-Şâm-l Şerîf der-yed-i } \\
\text { câbi-i vakf-ı şerîf. }\end{array}$ & 36.500 & \\
\hline & 3 & $\begin{array}{l}\text { 'An-mahsûl-ı mâl-ı mahrûse-i Misır ve maktû 'ât der- } \\
\text { yed-i câbi-i vakf-l şerîf. }\end{array}$ & 72.000 & \\
\hline \multicolumn{3}{|c|}{ 'An-mahsûl-ı kurahâ-i Evkâf-l şerîf-i mezbûre. } & \multicolumn{2}{|c|}{504.834} \\
\hline \multirow{12}{*}{ 'Ani'n-nukûd } & 1 & 'An-mahsûl-ı resm-i dels h. 483 & 5.014 & \multirow{12}{*}{132.794} \\
\hline & 2 & 'An-mahsûl-ı resm-i âdet-i ăgnam. & 9.973 & \\
\hline & 3 & 'An-mahsûl-ı resm-i âdet-i .... & 14.500 & \\
\hline & 4 & 'An-mahsûl-l resm-i hane. & 19.120 & \\
\hline & 5 & 'An-mahsûl-ı resm-i ..... & 20.520 & \\
\hline & 6 & 'An-mahsûl-ı resm-i eşcar-l zeytun. & 13.780 & \\
\hline & 7 & 'An-mahsûl-ı resm-i mu'tad. & 19.200 & \\
\hline & 8 & 'An-mahsûl-l resm-i rugan-l zeyt. & 10.439 & \\
\hline & 9 & 'An-mahsûl-ı resm-i cizye-i kurahâ. & 7.680 & \\
\hline & 10 & 'An-mahsûll-ı resm-i âdet..... & 3.601 & \\
\hline & 11 & 'An-mahsûl-ı resm-i kıta. & 7.167 & \\
\hline & 12 & 'An-mahsûl-ı resm-i ..... & 1.800 & \\
\hline \multirow{2}{*}{$\begin{array}{l}\text { 'Ani'l-gılâli 'an-kurahâ-i } \\
\text { vakıf hınta ve şâ 'ir bâ- } \\
\text { yed-i Halîli } \\
\text { Keyl } 1636\end{array}$} & 1 & Hinta keyl 885. & 248.600 & \multirow[b]{2}{*}{372.040} \\
\hline & 2 & Şâ ir keyl 751. & 123.440 & \\
\hline
\end{tabular}

Vakfa ait I. Muhasebe kaydına göre oldukça kısa olan bu II. Muhasebe kaydı daha önce de belirtildiği üzere 3 sayfadır. Yukarıda sunulan Tablo 7'ye göre vakfın gelirleri arasında \%54,68'lik en büyük paya sahip olan 'Ani'l-gllâlı 'an kurahâ-i vakıf hınta ve şâ 'îr başlı̆ğ altında toplu bir şekilde 12 kalemde kaydedilen ve vakıf köylerinden alınan buğday ve arpa gelirleridir. İkinci en büyük paya sahip vakıf gelirlerini \%17,71'lik oranla 'ani'l-müşı̂rât 
başlığı altında beş kalemde kaydedilen vakıf musakkafâtına ait kira gelirleri oluşturmaktadır. Üçüncü olarak vakıf gelirleri arasında \%15,05'lik bir orana sahip ve 'An Mahsûl-ı mütenevvi 'a başlığı altında üç kalemde kaydedilen el-Halil'de bulunan Sultan Gavri Vakfı'nın mahsulleri ile Şam ve Mısır'da bulunan mahsuller oluşturmaktadır.

Tablo 2 ve 6'da vakfa ait muhasebe kayıtları esas alınarak sunulan vakıf gelirleri karşılaştırıldığında; her iki muhasebe kaydında da öncelikle eski mütevelli elinde önceki yıldan kalan ve cari yılda vakıf gelirleri arasına dahil edilen gelirler yazılmıştır. Ancak vakfa ait diğer gelirlerin mevcut iki muhasebe kaydında farklı başlıklar altında toplandığı görülmektedir. $\mathrm{Bu}$ durumun gerekçesi birinci kaydının vakfın mütevellisi tarafından Kudüs Kadısına sunulduktan sonra Kadı'nın mührü ile Haremeyn vakıfları nâzırı olan darüssaade ağasına takdim edilirken; ikinci muhasebe kaydının vakfın kâtibi tarafından hazırlanarak vakfın mütevellisine sunulması olarak değerlendirilebilir. Bu bağlamda birinci muhasebe kaydı Osmanlı merkezi yönetiminin Haremeyn vakıfları denetmenine sunulan tafsilatlı bir muhasebesi olarak değerlendirilebilecekken, ikinci muhasebe kaydı hesapların denkleştirilmesine yönelik ön bir inceleme veya rapor görünümü arz etmektedir.

\section{Vakfin Giderleri}

Vakıfların mali durumu ve faaliyetleri hakkında yeterince güvenilir bilgiye ulaşabilmek için gelir ve gider tarafları birlikte analiz edilmelidir. Vakfa ait muhasebe kayıtlarından ilkinde vaz ' $ı$ mâl, ikincisinde ise vuzi 'a min zâlik başlıkları altında vakfın giderleri sıralanmıştır. Genel olarak el-vezâif (vazifelilerin/hizmetlilerin/görevlilerin maaşları) ve el-ihrâcât (çeşitli satın alımlar veya hizmetler için harcanan paralar) olmak üzere iki gruba ayrılan vakıf giderleri mevcut muhasebe kayıtlarından ilkinde oldukça detaylı bir şekilde sunulmuştur. Vakıf hizmetlilerinin maaşları en temel gider kalemini oluşturmuştur. Ayrıca vakfın işletilmesi, onarımı ve bakımı için gerekli mal, malzeme ve aletlerin satın alınması için imâret, mescit ve türbelerin harcamaları anbar, tenvîr (aydınlatma), ihrâcât (masraflar) ve ta 'âmiye-i mütevelli (mütevelli yemek masrafları) başlıkları altında detaylandırılan bahse konu vakıf giderleridir. Bu kalemlerin ardından tahsil edilmemiş gelirler de harcama tarafında listelenmiştir. Ve son olarak hesap, vakıf bütçesinde kalan açık veya nakit ile dengelenmiştir.

Vakfa ait II. Muhasebe kaydında ise, el-vezâif (görevli ücretleri) ve vâcibât (masraflar) başlıkları altında iki grupta vakıf giderleri kaydedilmiştir. 


\section{a. Vakfın I. Muhasebe Kaydına Göre Giderleri}

Vakfa ait I. Muhasebe kaydında vakfın gelir dağılımı şöyledir:

Tablo 8

Halilürrahman Vakfı'nın I. Muhasebe Kaydına Göre Giderleri (para)

\begin{tabular}{|l|l|c|r|}
\hline No & Vakıf Giderleri & $\mathbf{\%}$ & Miktar \\
\hline 1 & El-Vezâif(Görevli Ücretleri) & 48,6 & 409.528 \\
\hline 2 & Anbar (Anbar Masrafları) & 7,3 & 61.360 \\
\hline 3 & Tenvîr (Aydınlatma) & 4,4 & 37.080 \\
\hline 4 & İhrâcât (Harcamalar) & 32,6 & 274.428 \\
\hline 5 & Ta 'âmiye-i Mütevelli (Mütevellinin Yemek Masrafları) & 7,1 & 60.000 \\
\hline \multicolumn{2}{|l|}{ Toplam } & $\mathbf{1 0 0}$ & $\mathbf{8 4 2 . 3 9 6}$ \\
\hline
\end{tabular}

Tablo 8'de sunulan muhasebe kaydında vakfın giderleri arasında \%48,6'lık bir oranla en yüksek paya sahip, görevli ücretleridir. Görevli ücretlerini gider kalemleri arasında \%32,6'lık bir orana sahip el-ihrâcât başlığı takip etmiş, vakıf giderleri arasında ikinci sırayı almıştır. Gider kalemleri arasında \%7,3 lük orana sahip anbar masrafları, \%4,4'lük bir orana sahip aydınlatma masrafları ve $\% 7,1$ 'lik bir orana sahip mütevellinin yemek masrafları takip etmiştir. Vakıf giderleri toplamda beş ayrı kalemde yazılmıştır.

\section{aa. el-Vezâif (Görevli Ücretleri)}

Tablo 9'da görüleceği üzere toplamda 252 kişiden oluşan vakıf görevlileri 6 başlık altında kategorize edilmiştir. Bunlardan en kalabalık vakıfçalışanı grubunu genel hizmetli başlı̆ğ altında kategorize edilen huddâm (24), ferrâş (12), bevvâb (24), küttâb (61), câbî (8) oluşturmaktadır. Buna göre ikinci en kalabalık; hatip, imam, muvakkıt (18 kişi), imam-ı makâm-ı erba în (1), müezzinler (28) olmak üzere dini görevliler başlığı altında gruplanan vakıf görevlileri oluşturmuştur. Üçüncü grubu Cemâ 'ati musaddirîn ve müderrisîn 'an meşâyih-i harem-i şerîf başlığı altında kaydedilen 32 kişiden oluşan musaddır ve müderrisler oluşturmuştur. Dördüncü grupta diğer görevliler olarak gruplanan sübhagân (4), mürettebât-ı sade (16), mürettebât-ı ashâb-ı hayrât (1), cemâ 'at-i müste'min (1) bulunur. Beşinci grupta ise sosyal hizmet görevlileri başlığı altında kategorize edilen ve içerisinde simât görevlilerinin de olduğu vakıf çalışanları bulunmaktadır. Görevli sayısı itibariyle en son sırada bulunan ancak maaşları itibariyle vakıftan en fazla ücreti alan vakfın idari personeli yine ayrı bir başlıkta gruplandırılmıştır.

Vakfın diğer personellerinin sayı ve maaşları ise şöyledir: 
Tablo 9

Vakıf Personeli Sayıları ve Ücretleri

\begin{tabular}{|l|c|c|c|c|}
\hline Görevliler & $\begin{array}{c}\text { Personel } \\
\text { sayıst }\end{array}$ & $\begin{array}{c}\text { Ücretler } \\
\text { (yillık) }\end{array}$ & Personel/toplam personel & $\begin{array}{c}\text { Personel ücretleri/toplam } \\
\text { personel ücretleri }\end{array}$ \\
\hline Genel Hizmet & 129 & 99.695 & $129 / 252 \% 51,2$ & $99.695 / 409.528 \% 24.3$ \\
\hline Dini & 47 & 102.200 & $47 / 252 \% 18,7$ & $102.200 / 409.528 \% 24.9$ \\
\hline Eğitim & 32 & 34.940 & $32 / 252 \% 12,7$ & $34.940 / 409.528 \% 8.5$ \\
\hline Sosyal (Simāt) & 12 & 8.850 & $12 / 252 \% 4,7$ & $8.850 / 409.528 \% 2.1$ \\
\hline İdari & 6 & 133.920 & $6 / 252 \% 2,4$ & $133.920 / 409.528 \% 2.7$ \\
\hline Diğger Personel & 26 & 29.923 & $26 / 252 \% 10,3$ & $29.923 / 409.528 \% 9.3$ \\
\hline Toplam & $\mathbf{2 5 2}$ & $\mathbf{4 0 9 . 5 2 8}$ & $\mathbf{2 5 2} \% \mathbf{1 0 0}$ & \\
\hline
\end{tabular}

Tablo 9'da görüldügü üzere vakıf hizmetlileri ücretleri arasından sayıca az olmalarına rağmen en fazla ücreti alan grup idari personel grubudur. Cemâ'ati mütevelli ăga ve nâib-i nâzır ve başkâtib ve Rûznâmçe başlı̆̆ı altında toplam 6 personel, görev adı, görevli adı, ücreti (aynî ve nakdî), günlük ve yıllık olarak kaydedilmiştir. Örneğin vakfın mütevellisi el-Hac Hasan Ağa’ya tek kalemde yıllık olarak 14.400 para görevli ücreti olarak kaydedilmiştir. Vakfın nâzırı olarak kaydedilen Süleyman Bey, Derviş Bey ve evlâd-ı merhûm İbrahim olarak kaydedilen 3 kişinin gelirleri arasında; keyli 72 paradan 23.040 para değerinde buğday, keyli 72 paradan toplam 28.800 para kıymetinde arpa ve 100 para kıymetinde zeytinyağ 1 kaydedilmiştir. Vakfın başkâtibinin gelirleri ise; günlük 10 paradan yıllık 1.800 para, keyli 72 paradan 23.040 kıymetinde buğday ve 100 para kıymetinde zeytinyağı olarak verilmiştir. Vakfın idari görevlileri arasında kaydedilen, son görevli rûznâmçeci Şeyh Şahabeddin Efendi'nin görev ücretidir. Günlük 3 paradan, yıllık 1.080 para nakdî maaş ile birlikte keyli 72 paradan yıllık 23.040 para buğday, keyli 72 paradan y1llık 11.520 para arpa ve 50 para kıymetinde zeytinyağı rûznâmçecinin görev ücreti olarak kaydedilmiştir. Burada kısaca bahsedildiği üzere, vakfın en fazla ücret alan idari personeli arasından mütevelli dışındaki görevlilerin nakdî gelirleri yanında aynî gelirleri de mevcuttur. Bu durumun gerekçesi olarak da vakfin giderleri arasında tek kalemde, detay belirtilmeden "Be cihet-i ta 'âmiye el-Hac Hasan Ağa el-Mütevelli 'ale'l-vakf-ı şerîf'” başlığı altında kaydedilen ve vakıf gider bütçesinin \%7,1'lik kısmını oluşturan gider kalemi gösterilebilir. Zira mütevelliye yapılan aynî ödemeler ile mütevellinin yemek masrafları bu gider başlığı altında kaydedilmiştir.

Muhasebe kaydında en kalabalık hizmetli grubunu oluşturan genel hizmet görevlilerinden Cemâ'at-i huddâm-ı makamâtı'l-enbiyâi'l-izam ve zevcâtihim et-tahirat el-kiramû 'aliyhim es-selatu ve's-selam başlığı altında kaydedilen huddâmların (24) görevlileri ve ücretleri şöyledir: 
Tablo 10

Vakıf Hizmetlilerinden Hademelerin Ücretleri

\begin{tabular}{|c|c|c|c|}
\hline No & Görevli Adı & $\begin{array}{c}\text { Ücreti } \\
\text { (günlük/para) }\end{array}$ & $\begin{array}{c}\text { Ücreti } \\
\text { (yıllık/para) }\end{array}$ \\
\hline 1 & Vazîfe-i eş-Şeyh Ahmed ve ahaveyhi huddâm-ı Hazreti Halilullah & 3 & 1.080 \\
\hline 2 & Vazîfe-i Evladı Salih es-Sa'ade hüddâm-ı Hazreti Halilullah. & 1,5 & 540 \\
\hline 3 & Vâzife-i Evladı Şemseddin hüddâm-ı Halilullah. & 2 & 840 \\
\hline 4 & Vazîfe-i Evladı Ísmail hüddâm-ı Hazreti Halilullah. & 1,5 & 540 \\
\hline 5 & Vazîfe-i Evladı Şeyh Mustafa hüddâm-ı İshak. & 1,5 & 540 \\
\hline 6 & Vazîfe-i Evladı Şeyh Mustafa hüddâm-ı İshak. & 1,5 & 540 \\
\hline 7 & Vazîfe-i Evladı Ebussuud hüddâm-ı Hazreti Ishak & 1,5 & 540 \\
\hline 8 & Vazîfe-i Evladı müsevvede hüddâm-ı İshak. & 1,5 & 540 \\
\hline 9 & Vazîfe-i Evladı Eyadi hüddâm-ı Hazreti Sarra & 1,5 & 540 \\
\hline 10 & Vazîfe-i Evladı müsevvede hüddâm-ı Hazreti İshak. & 3 & 540 \\
\hline 11 & Vazîfe-i Mehmed Süleyman hüddâm-ı Hazreti İshak & 1,5 & 225 \\
\hline 12 & Vazîfe-i Evladı Ísmail hüddâm-ı İshak & 1,5 & 540 \\
\hline 13 & Vazîfe-i Evladı Delum hüddâm-ı Hazreti Yakub & 1,5 & 540 \\
\hline 14 & Vazîfe-i Evladı Şerafeddin hüddâm-ı Hazreti Yakub & 1,5 & 540 \\
\hline 15 & Vazîfe-i Evladı Abdulhalim hüddâm-ı Yakub & 1,5 & 540 \\
\hline 16 & Vazîfe-i Salih ve İsa hüddâm-ı Hazreti Yakub & 1,5 & 540 \\
\hline 17 & Vazîfe-i Şeyh Mustafa ve ahaveyh hüddâm-ı Hazreti Yusuf. & 3 & 1.080 \\
\hline 18 & Vazîfe-i Evladı Şerafeddin hüddâm-ı Yusuf. & 1,5 & 540 \\
\hline 19 & Vazîfe-i Seyyid Salah Hadim-i Yusuf. & 4 & 1.440 \\
\hline 20 & Vazîfe-i Evladı Alaeddin hüddâm-ı Gâr & 1,5 & 540 \\
\hline 21 & Vazîfe-i Evladı Ebu'l-vefa hüddâm-ı Gâr. & 3 & 1.080 \\
\hline 22 & Vazîfe-i Şeyh Mustafa Mervani. & 1,5 & 540 \\
\hline 23 & Vazîfe-i es-Seyyid İbrahim hâdim-i Kubbe-i Ezvac & 2 & 730 \\
\hline 24 & Vazîfe-i Alaeddin Hâdimi ... & 1,5 & 540 \\
\hline \multicolumn{2}{|c|}{ Toplam } & 45,5 & 15.115 \\
\hline
\end{tabular}

Tablo 10'da görüldüğü üzere vakıf görevlileri arasında 24 kişi olarak kaydedilen hademeler çoğunlukla Peygamber kabirlerinin hizmetinden sorumludurlar. Günlük 1,5 ila 3 para arasında değişen ücretler alan hademelere buğday, arpa ya da zeytinyağı gibi tahsisatlar yapılmamıştır.

Vakıf görevlileri arasında sayıları 61 olan kâtiplerin sayısı da dikkat çekicidir. Bu durum ise vakfın büyüklüğü ile açıklanabilir. Kâtipler gibi vakıf gelirlerinin tahsilinden sorumlu câbîler de sayıca fazladır. 
Tablo 11

Vakıf Hizmetlilerinden Câbîlerin Ücretleri

\begin{tabular}{|l|l|c|r|}
\hline No & $\begin{array}{l}\text { Cemaat-i Câbiyan-ı Mahasılı'l-Vakfi'ş-şerif an-vâcib sene 1117 } \\
\text { 5.220 para }\end{array}$ & $\begin{array}{c}\text { Miktar } \\
\text { (günlük/para) }\end{array}$ & $\begin{array}{r}\text { Ücret (yıllık/ } \\
\text { para) }\end{array}$ \\
\hline 1 & Vazîfe-i Şeyh Halil Câbi-i Haleb. & 3 & 1.080 \\
\hline 2 & Vazîfe-i Şeyh Ahmed Ensâri câbi-i Mısır. & 2 & 1.440 \\
\hline 3 & Vazîfe-i Şeyh Mustafa Tahsub Câbi-i Şam. & 7 & 2.520 \\
\hline 4 & Vazîfe-i Evladı Delum Câbi-i Cenin el-Celil. & 2 & 1.080 \\
\hline 5 & Vazîfe-i Mustafa Kadı Câbi-i Mısır. & 1,5 & 720 \\
\hline 6 & Vazîfe-i Mustafa Kadı Câbi-i Benisehle. & 1,5 & 450 \\
\hline 7 & Vazîfe-i Şeyh Mehmed Müsevvede-i Câbi-i Benisehle. & 2 & 450 \\
\hline 8 & Vazîfe-i Ahmed Şerafeddin Câbi-i Beyti Luba. & 22 & 720 \\
\hline \multicolumn{2}{|c|}{ Toplam } & & 8.460 \\
\hline
\end{tabular}

Tablo 10'da görüldüğü üzere vakıf gelirlerinin tahsilinden sorumlu câbîler, Halep, Şam, Mısır, Cenin gibi vakıf musakkafât ve müstegallâtı bulunan yerlerin gelirlerinin toplanmasından sorumlu idiler. Câbîler arasından en yüksek günlük ve yıllık geliri ise vakfın Şam'daki gelirlerini toplamaktan sorumlu Mustafa Tahsup almıştır. Onu Halep ve Cenin câbîleri takip etmiştir.

\section{$a b$. Anbar Masrafları}

Vakfa ait I. Muhasebe kaydında anbar masrafları 32 kalemde kaydedilmiştir. Kaydın başında yer alan 'An-masârıf-ı Medine-i Anbar-ı Şerif li-ecli'l-vâridin ve levâzımı'l-evkâf ve alef-i ..... ve re'âyâ ve ta'âmiyât-ı el-vâridîn li-ziyareti'l-enbiya'i'l-kirâm aleyhim efdalu's-salat ve etemmü's-selâm min gurre-i Şehri'l-Muharremi'l-Haram min şuhûri sene 1117 ila gurreti'l-Muharrem sene 1118. Ahsenallahu hitâmehâ ifadeleri bu başlı̆̆1 özetler niteliktedir. El-Halil'de bulunan Peygamber kabirlerini ziyarete gelenler için ikram edilen yemek masrafları bu kalemde en fazla yer alan harcamalardır. Ayrıca, Haremü'l-Halil'e gelen vakıf re 'âyâsı (ahalisi) ile tulumbacıbaşı, Osman Ağa cemaati, Süleyman Paşa, İbrahim Paşa Cemaati gibi diğer bazı kişi ve görevlilere ait alef (yonca, hayvan yemi) ücretleri anbar masrafları içerisinde dokuz kalemde kaydedilmiştir.

\section{ac. Tenvîr (Aydınlatma Masrafları)}

“Masârıf-ı tenvîr iş 'âlât-ı kanâdili'l-Mescidi'ş-Şerîf ve Makamâti'l-Enbiya'i'l-izam aleyhim es-Selatu ve etemmü's-Selam ve iş 'âlâtı Sadâtı Şehr-i Ramazan ve İş'âl-ı vâridin ve Evliyâ ve gayru zâlik. Rugan-ı Zeyt 927 kıyye 37080 para." başlığı altında kaydedilen aydınlatma giderleri 24 kalemde şöyle detaylandırılmıştır. 
Tablo 12

Vakfin Aydınlatma Masrafları

\begin{tabular}{|c|c|c|}
\hline No & Aydınlatma Yeri & Miktarı (kıyye) \\
\hline 1 & İş'âli'l-Mescidi'ş-şerîf & 171 \\
\hline 2 & İş'âli’l-husubeyn & 43 \\
\hline 3 & İş'âli'l-Makamât-ı Enbiyâ & 428,5 \\
\hline 4 & $\dot{I}_{S ̧}^{\prime} a l-l \ldots .$. & 16 \\
\hline 5 & $\dot{I}_{\text {Ş ‘al-i Sâdât-ı Ramazan }}$ & 31 \\
\hline 6 & $\dot{I}_{\text {I̧ ‘al-i Teravih-i Ramazan }}$ & 7 \\
\hline 7 & $\dot{I S S}_{\text {sal-i Muvakkttini'l-Harem }}$ & 12 \\
\hline 8 & 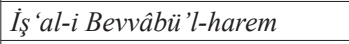 & 8 \\
\hline 9 & $\dot{I}_{\text {ş 'al-i Bevvâb-ı Anbar }}$ & 4 \\
\hline 10 & $\dot{I}_{S ̧}$ 'al-i Şeyh Ömer Veliyullah & 12 \\
\hline 11 & İş 'al-i eş-Şeyh Veliyullah & 8 \\
\hline 12 & $\dot{I}_{\text {ş ‘al-i Şeyh Lehfus Veliyullah }}$ & 4 \\
\hline 13 & $\dot{I}_{\text {Iş 'al-i Şeyh Burhaneddin }}$ & 12 \\
\hline 14 & $\dot{I}_{\text {Ş 'al-i Mescid-i Kal'a }}$ & 12 \\
\hline 15 & $\dot{I}_{S ̧}$ 'al-i Naibi Nazır & 49 \\
\hline 16 & $\dot{I}_{\text {Ş 'al-i Kâtib-i Hazine }}$ & 36 \\
\hline 17 & $\dot{I}_{\text {Ş }}$ al-i Neccar & 12 \\
\hline 18 & $\dot{I S S ̧}^{\prime} a l-i$ Sûk & 14 \\
\hline 19 & $\dot{I}_{\text {Ş }} a l-i \ldots . . . . \breve{g} a$ & 12 \\
\hline 20 & 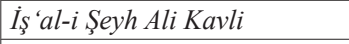 & 3 \\
\hline 21 & Gare...... & 1 \\
\hline 22 & 'Asel-i Kanâdil & 1,5 \\
\hline 23 & Vâridîn & 5,5 \\
\hline 24 & Hamam ve Kalemiye...... & 13 \\
\hline \multicolumn{2}{|c|}{ Toplam } & 927 \\
\hline
\end{tabular}

Tablo 12'de yer alan aydınlatma masrafları kıyye olarak kaydedilmiş olup, kalem kalem ücret tutarı yazılmamıştır. Toplam aydınlatma masrafları ise gider kaleminin yazıldığı başlıkta topluca kaydedilmiştir. Bahse konu aydınlatma giderleri arasında Peygamber makamları, makamların kapıları, mescid, Haremü'l-Halil kapısı, anbar kapısı, Ramazan ayında teravih için, sâdât için aydınlatma, şeyhlerin makamlarının aydınlatılması, kale mescidinin aydınlatılması kaydedilmiştir. Bunun yanı sıra vakıf görevlilerinden nâib-i nâzır, kâtib-i hazîne gibi idari görevlilere de bütçenin bu başlığından pay ayrılmıştır. Öte yandan, neccâr (marangoz), hamam ve çarşının aydınlatılması bu başlıkta kaydedilen diğer bazı harcama kalemleridir.

Bu öğeler arasında en büyük pay, yılda 428 buçuk kıyye maliyeti olan Peygamberlerin türbelerinin aydınlatılmasıdır. Ayrıca, örneğin mescidin aydınlatmasının maliyeti 171 kıyye iken, kale mescidinin aydınlatmasının yıllık maliyeti 12 kıyyedir. Öte yandan haremin kapılarının aydınlatılmasının maliyeti 8 kıyye, depo kapılarının aydınlatılması 4 kıyyedir. Toplamda 24 kalemde kaydedilen bu aydınlatma masrafları vakıf bütçesi içerisinde ise $\% 4,4$ 'lük oran ile vakıf giderleri arasında son sırada yer almıştır. 


\section{ad. el-ïhrâcât (Masraflar)}

Vakfın giderleri arasında \%32'lik bir oran ile ikinci sırada yer alan ihrâcât giderleri muhasebe kaydında “Be-cihet-i İhrâcâtı.... Mühimme fi-levâzımı'l-vakf-l şerif ve ücretu nakli gllâl-l irdeb ve Hıla-i Meşayihu'r-Re 'âyâ ve ta 'âmiye-i vâridin ila ziyareti'l-enbiyâi'l-kirâm 'ala Nebiyyinâ ve aleyhim ve alâ sairi'l-enbiyai'l-izâm afdalu's-salat ve etemmü 's-selâm ve ücreti.... Er-re 'âyâ ve gayru zâlik be-mûcebi defâtir-i küttabi'n-Nevâhî min gurre-i Şehri'lMuharremü'l-Haram sene 1117 ila intihâ-i şehri Zilhicceti'l-Haram sene tarihûhu” altında kaydedilmiştir. 52 kalemde kaydedilen gider kalemlerini özetler nitelikteki bu başlıkta vakfın fiili işleyişi için lüzum duyulan her türlü malzeme ve hizmet satın alımlarının kaydedildiği muhasebe başlığı olmuştur. Bunlar içinde cami mihrabının mumları, kırtasiye malzemesi, câbilerin harcırahı, hüccet için ödenen harçlar, kap kacağın kalaylanması masrafları benzeri çok çeşitli ufak masraf kalemleri yer almaktadır. Vakfın çeşitli hizmetlerin gördürülmesi için ödediği ücretler de bu başlıkta kayıtlıdır. Bu ödemeler içinde vakıf buğdayının anbardan değirmene ve unun değirmenden anbara taşınması için arabacılara ödenen ücret, değirmencilere ödenen ücret, vakfın tahsil ettiği mahsulün nakli için arabacılara ve satın alınan gıda mallarının ve odunun taşınması için hamallara ödenen ücretler benzeri ödemeler yer almaktadir.

Bunlara ek olarak, yerel önde gelen seçkinlerin yemek masrafları, yemek pişirme aletlerinin işçilik maliyeti, konuklar için ziyafet maliyeti, cami ve imâret alanındaki türbelerin bakımı da bu başlık altında kaydedilmiştir. Ayrıca Haremü'l-Halil'de bulunan peygamber makamlarını ziyarete gelenler ile vakıf re'âyâsının yemek masrafları da yine bu başlık altında kaydedilmiştir.

Bu kalemlere ilişkin bazı örnekler şöyledir:

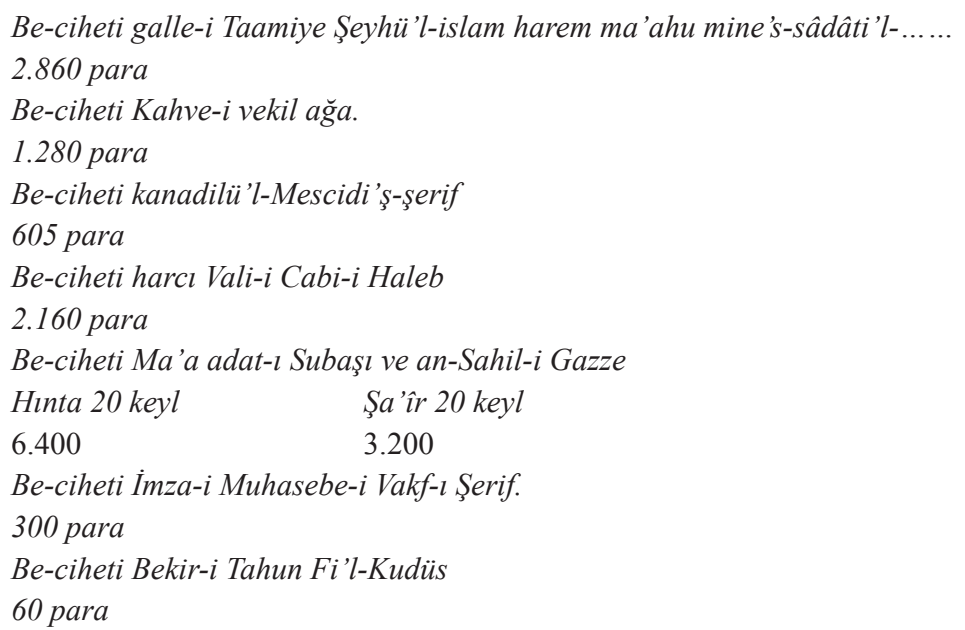


Be-ciheti Kahve ve Nûş ve Tahsil-i bi'r-Reşide ve Alisan

690 para

Be-ciheti Imare-i Ubur-ı Sebil an-yed-i İbrahim A ̆ga

1.954 para

Be-ciheti adet-i Kâtib-i Sahil-i Gazze

300 para

Be-ciheti adet-i Kâtib-i Anbar Sahil-i Gazze

300 para

Be-ciheti Müşteri-i Hacer-i Tahun der-Kudüs

5.900 para

Be-ciheti fi Imareti Ayni Hamam

1.104 para

Be-ciheti Hanefeyni fi Imareti'l-hamam

800 para

Be-ciheti Taamiye-i Çuhadar İbrahim Paşa

270 para

Be-ciheti baha-i keyli anbar

90 para

Be-ciheti seferi ile'l-Babi Âli fi Masâlihi'l-vakfi'ş-şerif

18.000 para

Be-ciheti Hazreti İbrahim Paşa Vali-i Gazze sâbıkan li-ecli himayeti Biladi'l-vakıf bi-

Nahiye-i Gazze ve Remle.

54.000 para

Be-ciheti tasarruf fi yed-i eş-Şeyh Halil Efendi fi vekâleti meblağı huzurı 'l-mütevelli

3.000 para

Be-ciheti kâğı ve Levâzım-ı zamanı'l-Muhasebe ve Harcı Kitab

900 para

Burada yer verilen örneklerde de görüldüğü üzere el-ihrâcât başlığı altında vakfın çok çeşitli giderleri kaydedilmiştir.

Vakıf mülklerin tamir ve bakımlarına ilişkin ayrı bir başlık açılmamıştır. Bunun yerine el-ihrâcât başlığı altında aşağıda yer verilen iki kalemde kaydedilmiştir.

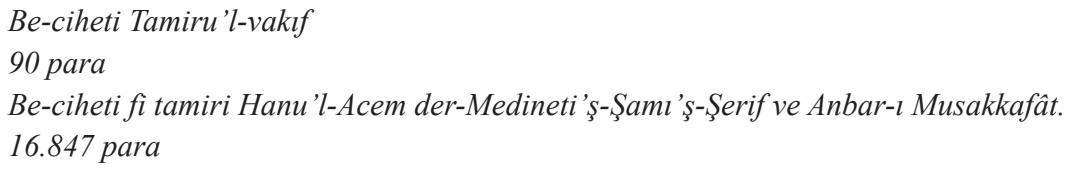

Burada yer verilen iki kalemden ilki oldukça cüz'i bir miktar tamir gideri olarak kaydedilmişken, ikinci kalemde vakfın Şam'da bulunan Acem Hanı ile anbarın tamir masrafı 16.847 para olarak yazılmıştır. 


\section{ae. Ta'âmiye-i Mütevelli (Mütevelli Yemek Masrafi)}

Halilürrahman Vakfı'na ait I. Muhasebe Kaydında ta 'âmiye-i mütevelli olarak kaydedilen gider kalemi başlığ şöyledir: "Be-cihet-i Taamiye-i Kıdvetü'l-a'yân el-mu'teberin el-Hac Hasan Ăga el-mütevelli ale'l-vakfi'ş-şerif bi-muktezâ-i âdât-ı kadîme 'an-vâcib sene 1117 bi-mûcibi Muhasebât-ı sâbıka.60.000 para."

$\mathrm{Bu}$ başlıktan da anlaşılacağı üzere eski bir gelenek olarak mütevelliye yemek masrafı başlığı altında muhtemelen kendisine diğer idari personelde olduğu gibi tahsis edilen mahsuller ya da kendisini ziyarete gelenlere ikram edilen yemek masraflarına ilişkin kayıt tek kalemde 60.000 para olarak kaydedilmiş olmalıdır.

\section{b. Vakfın II. Muhasebe Kaydına Göre Giderleri}

Halilürrahman Vakfi'na ait H. 1118/M. (Mart) 1807-1808 tarihli muhasebe defterinde yer alan ikinci muhasebe kaydında vakfın giderleri "el-vezâif" ve "vâcibât" olmak üzere iki başlık altında kaydedilmiştir.

Tablo 13

Halilürrahman Vakfı'nın II. Muhasebe Kaydına Göre Giderleri (para)

\begin{tabular}{|c|c|c|c|c|c|}
\hline & \multicolumn{3}{|c|}{ Vakıf Giderleri } & $\%$ & Miktar \\
\hline 1 & \multicolumn{3}{|c|}{ El-vezâif (Personel) } & 51,41 & 387.588 \\
\hline \multirow{3}{*}{2} & \multirow{3}{*}{$\begin{array}{l}\text { Vâcibât } \\
\text { (Masraflar) }\end{array}$} & Harc-l matbah (Mutfak harcamaları) & 158.440 & \multirow{3}{*}{48,59} & \multirow{3}{*}{366.324} \\
\hline & & Muhasebât-ı evkâf- sâire (Diğer harcamalar) & 189.043 & & \\
\hline & & Meremmet (Tamirat masrafları) & 18.841 & & \\
\hline \multicolumn{4}{|c|}{ Toplam } & 100 & 753.912 \\
\hline
\end{tabular}

Tablo 13 'te verilen bilgiler incelendiğinde; vakfın giderleri arasında \%51,41'lik orana sahip vakıf personelinin maaşları, muhasebe kaydında tek kalemde, toplu bir şekilde kaydedilmiştir. Öte yandan "vâcibât" başlığı altında vakıf giderlerinin \%48,59'unu oluşturan masraflar, mutfak giderleri, diğer masraflar ve tamir masrafları olmak üzere üç ayrı başlıkta 33 kalemde kaydedilmiştir. Çalışmanın bu kısmında vâcibât başlığı altında kaydedilen harcamalara sırası ile yer verilecektir.

\section{ba. Harc-ı Matbah (Mutfak Masrafları)}

Vakfın vâcibât başlığı altında kaydedilen be-cihet-i harc-ı matbah berâ-yı masarıfât-ı simât-ı Hazret-i müşârun ileyh (mutfak harcamaları) 3 kalemde şöyledir: 
Tablo 14

Vakfın II. Muhasebe Kaydına Göre Mutfak Masrafları

\begin{tabular}{|c|c|c|}
\hline No & Masraf Kalemleri & Ücreti (para) \\
\hline 1 & 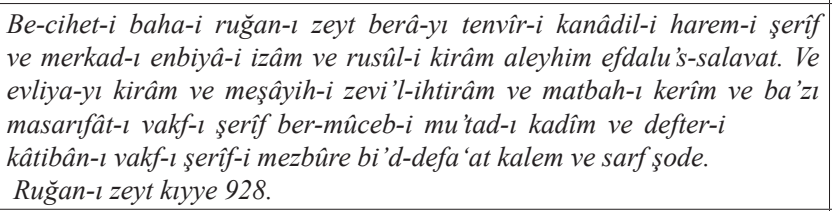 & 37.080 \\
\hline 2 & $\begin{array}{l}\text { Be-cihet-i baha-i hınta ve şâ ir ve dels ve alef ve baha-i nân ve baha-i } \\
\text { kahve ve masarı̂ât- sâire berâ-yl matbah-ı Hazreti Halilurrahman } \\
\text { salavatullahi alâ nebiyyina ve aleyhisselam } \\
\text { ve fukara-i varidîn-i müslimîn ber-mûceb-i âdet-i kadîm } \\
\text { ve defter-i kâtibân-l vakıf bi'd-defa'at sarf şode. }\end{array}$ & 61.360 \\
\hline 3 & $\begin{array}{l}\text { Be-cihet-i harcı ta 'am baha-i mütevelli-i vakf ve hüddâm-l vakf ve } \\
\text { re 'âyâ-yı kurahâ. } \\
\text { Ve baha-i kahve ve masarıfât-l sâire ber-mûceb-i mu'tad-ı kadîm } \\
\text { ve defter-i kâtibân-l vakf bi'd-defa 'at sarf şode. }\end{array}$ & 60.000 \\
\hline \multicolumn{2}{|r|}{ Toplam } & 158.440 \\
\hline
\end{tabular}

I. Muhasebe kaydı ile kıyaslandığında üç kalemde toplu bir şekilde kaydedilen bu mutfak masrafları arasında ilk kalemde içerisinde simât (Halil İbrahim Sofrası)'ın da bulunduğu harem-i şerif ve merkad-ı enbiyâ gibi makamların aydınlatma masrafları için 928 kıyye zeytinyağı bedeli 37.080 para kaydedilmiştir. İkinci ve mutfak masrafları içerisindeki en fazla gider kalemini oluşturan ise; buğday, arpa, yulaf, ekmek ve kahve ile diğer mutfak masrafları olmuştur. Simât'a gelen fakir Müslümanlara gelenek olduğu üzere ikram edilen yemeklerin masrafı da bu kalemde kaydedilmiştir. Mutfak masrafları içerisinde üçüncü kalemde kaydedilen masrafları ise; mütevelli, vakıf hizmetlileri ve vakıf köylerinin re‘âyâlarının yemek masrafları ile kahve ve gelenek olan diğer masraflar oluşturmuştur.

Vakfa ait bu II. Muhasebe kaydında tanımlanan mutfak masrafları incelendiğinde; ilk dikkati çeken husus simât'a gelenlerin yemek masrafları ile vakıf personelinin yemek masraflarının ayrı ayrı kaydedilmiş olmasıdır. Böyle bir farklılığın ikram edilen yemeklerde de olup olmadığ 1 sorusu burada verilen bilgilerle cevaplanamayacak bir soru olarak karşımıza çıkmaktadır. Öte yandan mutfak harcamaları arasında kaydedilen kahve giderleri dikkat çekicidir. Seyyahların ya da hacıların hakkında bir malumat vermediği kahve tüketimi, simât giderleri arasında önemli harcamalar arasında yazılmıştır.

Simât'a ait herhangi bir tamir masrafına rastlanmazken, diğer harcama kalemleri arasında yazılan örneğin be-cihet-i harc-ı ziyâfet-i Şeyhülislam kasaba-i Halilurrahman ve sâdât ber-mûceb-i âdet-i kadîm başlığında kaydedilen 2.860 para; be-cihet-i baha-i kahve berâ-yı zâbıtan-ı vakıf başlığında kayıtlı 6.196 para da mutfak masrafları arasına dâhil edilebilecek vakıf muhasebe defterinin diğer harcamaları arasında kayıtlı masraflardandır. Zâbıtân-ı vakıf terimi vakfın idari kadrosu için kullanılan bir terim olması hasebiyle yukarıda zikredilen 
kahve masraflarına ilaveten ayrı bir kalemde tekrar bir kahve giderinin yazılmasından işaret ettiğimiz gibi simât’ta çokça kahve tüketildiği anlaşılmaktadır.

\section{bb. Muhasebât (Muhasebe Giderleri)}

Vakfın II. Muhasebe kaydında gelir kalemleri arasında muhasebât-ı evkâf-ı sâire-i mezkûrîn başlığı altında yine çeşitli harcamalar 28 kalemde kaydedilmiştir. Çoğunlukla vergilerin kaydedildiği bu gider başlığında vakıf giderleri toplu bir şekilde kaydedildiği için aşağıda tablo halinde sunulmuştur.

Tablo 15

Muhasebât Giderleri

\begin{tabular}{|c|c|c|}
\hline 1 & $\begin{array}{l}\text { Be-cihet-i baha-i hil 'at berâ-yı meşâyih-i esâmi Gazze ve Nablis ve kurahâ-i sâire ber-mûceb-i } \\
\text { mu'tad-ı kadîm sarf şode. }\end{array}$ & 18.860 \\
\hline 2 & $\begin{array}{l}\text { Be-cihet-i baha-i kanâdil berâ-yı mescid-i şerîf-i Hazreti Halilurrahman ber-mûceb-i mu'tad-l } \\
\text { kadîm sarf şode. }\end{array}$ & 605 \\
\hline 3 & $\begin{array}{l}\text { Harc-l mevlid-i şerîf ve meddah-l şerîf-i Hazret-i Resûl-i Ekrem ve Nebiyyi muhterem } \\
\text { sallallahu Teâla aleyhi ve's-selem. Ber-mûceb-i mu'tad-ı kadîm sarf şode. }\end{array}$ & 860 \\
\hline 4 & $\begin{array}{l}\text { Be-cihet-i harc-ı ziyâfet-i Şeyhü'l-İslam kasaba-i Halilurrahman ve sadât. } \\
\text { Ber-mûceb-i mu'tad-ı kadîm sarf şode. }\end{array}$ & .60 \\
\hline 5 & $\begin{array}{l}\text { Be-cihet-i harc-ı kaydı berât-ı şerîf 'âlişsan ve tevliyet-i vakf-l şerîf. Ber-mûceb-i mu 'tad-ı } \\
\text { kadîm sarf şode. }\end{array}$ & 2.400 \\
\hline 6 & Be-cihet-i ücret-i nefsi gllâl 'an-kurahâ-i câbi-i anbar-ı kerîm. Bi'd-defa 'at harç ve sarf şode. & 1.740 \\
\hline 7 & $\begin{array}{l}\text { Be-cihet-i baha-i kahve bera-yı ... zabıtân vakf ve hüddâm-ı mütevelli re 'âyân 'an-muhassal-ı } \\
\text { tahsîl-i gılâl. Ber-mûceb-i âdet-i kadîm sarf şode. }\end{array}$ & 6.196 \\
\hline 8 & Be-cihet-i harç-ı râh-ı câbiyan berâ-yı tahsîl-i mâl-ı vakıf. Ber-mûceb-i âdet-i kadîm sarf şode. & 2.160 \\
\hline 9 & Be-cihet-i Harc-ı Subaşı berâ-yı tahsil-i mal-ı vakf-l şerif. Bi'd-defa 'at sarf şode. & 9.600 \\
\hline 10 & $\begin{array}{l}\text { Be-cihet-i harc-ı imzâ-i Kâdî-i Kudüs-i Şerîf berâ-yı defter-i muhasebe-i vakf-ı şerîf. } \\
\text { Ber-mûcebi bi'd-defa 'at sarf şode. }\end{array}$ & 3.000 \\
\hline 11 & $\begin{array}{l}\text { Be-cihet-i ücret-i katibân ve anbarl der-surre-i gurre berâ-yı tahsil-i mâl-l vakf ber-mûceb-i } \\
\text { addet-i kadîm bi'd-defa 'at sarf şode. }\end{array}$ & 1.500 \\
\hline 12 & $\begin{array}{l}\text { Be-cihet-i edâ-i hademe-i muhassıllık berâ-yı tahsîl-i mâl-l vakf ber-mûceb-i âdet-i kadîm. } \\
\text { Bi'd-defa' 'at harç ve sarf şode. }\end{array}$ & 4.800 \\
\hline 13 & $\begin{array}{l}\text { Be-cihet-i harc-ı ta'am-ı fukarâ-i vâridîn ve Çukadar İbrahim Paşa ve it'am-ı âaire. } \\
\text { Bi'd-defa 'at sarf şode. }\end{array}$ & 2.374 \\
\hline 14 & $\begin{array}{l}\text { Be-cihet-i ücret-i mübâşir berâ-yı tahsîl-i mal-ı vakf-ı şerîf. } \\
\text { Bi'd-defa 'at harç ve sarf şode. }\end{array}$ & 10.920 \\
\hline 15 & $\begin{array}{l}\text { Be-cihet-i ücret-i Çukadar Paşa Gazze berayı mesalih-i vakıf. } \\
\text { Bi'd-defa 'at sarf şode. }\end{array}$ & 960 \\
\hline 16 & $\begin{array}{l}\text { Be-cihet-i ücret-i sâ-i berâ-yı mesâlih-i vakf-ı şerif. } \\
\text { Bi'd-defa 'at sarf şode. }\end{array}$ & 1.080 \\
\hline 17 & $\begin{array}{l}\text { Be-cihet-i harc-ı hademe-i Mehmed Paşa ve İbrahim Paşa vâlî-i Gazze. } \\
\text { Bi'd-defa 'at sarf şode. }\end{array}$ & 5.400 \\
\hline 18 & $\begin{array}{l}\text { Be-cihet-i Harc-ı Nâib-i Kâdî-i Kudüs-i Şerîf bera-yı mesâlih-i vakıf. } \\
\text { Bi'd-defa 'at sarf şode.. }\end{array}$ & 108.000 \\
\hline 19 & $\begin{array}{l}\text { Be-cihet-i Harc-ı ba'zı masarıfât tahun der-Kudüs-i şerif. } \\
\text { Bi'd-defa 'at sarf şode.. }\end{array}$ & 6.230 \\
\hline 20 & $\begin{array}{l}\text { Be-cihet-i Harc-ı masarıfât-ı Halil Efendi vekil-i mütevelli-i vakıf. } \\
\text { Bi'd-defa 'at sarf şode. }\end{array}$ & 3.000 \\
\hline
\end{tabular}




\begin{tabular}{|c|c|c|}
\hline 21 & Baha-i Kâğıt berâ-yı levâzım-ı defâtir-i vakf-ı şerif bi'd-defa 'at sarf şode. & 900 \\
\hline 22 & Baha-i ganem berâyı ......bi'd-defa 'at sarf şode. & 5.900 \\
\hline 23 & Edâ-i akçe-i Mustafa Paşa vâli-i Kudüs-i şerif sâbıkan an-mesâlih-i vakf-ı şerif sarf şode. & 20.940 \\
\hline 24 & $\begin{array}{l}\text { Edâ-i akçe-i İbrahim Paşa vâli-i Gazze ve Remle sâbıkan berâyı masâlih-i vakf-ı şerif bi'd- } \\
\text { defa 'at sarf şode. }\end{array}$ & 54.000 \\
\hline 25 & $\begin{array}{l}\text { Harç-ı ba 'zı masarıfât-ı hammamânı vakf-ı şerîf ber-mûceb-i âdet-i kadîme bi'd-defa 'at sarf } \\
\text { şode. }\end{array}$ & 1.458 \\
\hline 26 & Harç-ı imzâ-i Mevlâna Müfettiş Efendi der-hîn-i dîde-i muhasebe-i vakıf. & 300 \\
\hline 27 & Harç-ı kisedâriye ve hüddâmiye ve kalemiye ber-mûceb-i âdet-i kadîme sarf şode. & 1.000 \\
\hline 28 & Harç-ı dîde-i muhasebe-i vakıf ber-mûceb-i mu'tad-ı kadîme sarf şode. & 2.000 \\
\hline \multicolumn{2}{|r|}{ Toplam } & 189.043 \\
\hline
\end{tabular}

\section{bc. Meremmet (Tamir Masrafları)}

Vakfın giderlerinin son başlığını oluşturan 'ani'l-meremmet-i mezkûrîn başlığı altında iki kalemde tamir masrafları kaydedilmiştir.

Tablo 16

Vakfin Tamirat Masrafları

\begin{tabular}{|l|l|c|}
\hline 1 & $\begin{array}{l}\text { Harç-ı meremmet-ı kazgan-ı hammam-ı kasaba-i Hazreti Halilu'r-Rahman ber-mûceb-i } \\
\text { defter-i kâtibân-ı vakıf bi'd-defa 'at sarf şode. }\end{array}$ & 1.994 \\
\hline 2 & $\begin{array}{l}\text { Harç-ı meremmet-ı kazgan-ı Han der-Şam-ı şerif bi'd-defa'at ber-muceb-i defter-i kâtibân } \\
\text { sarfşode. }\end{array}$ & 16.847 \\
\hline \multicolumn{2}{|l|}{ Toplam } & $\mathbf{1 8 . 8 4 1}$ \\
\hline
\end{tabular}

Buna göre cari yıl içerisinde el-Halil kasabasında bulunan hamamın kazanı ile Şam'da bulunan hanın kazanı tamir edilmiştir.

\section{c. El-Bâkî (Kalan)}

Halilürrahman Vakfi'na ait her iki muhasebe kaydında da giderler bölümü hesapları el bâkî (kalan) hesaplanması ile devam etmiştir. Bua göre, vakfın birinci hesap kaydında derzimem-i re'âyâ-yı kurahâ ve müste'cirîn 'an vâcib sene 1117 bi-mûcib-i defâtîr-i küttâbü'nnevâhî başlığı altında listelenmiştir. Daha önce de belirtildiği gibi, cari döneme ait tahsil edilmemiş gelirler, birinci hesap defterinin başlangıcında, makbûz (toplanan) ve bâkî (kalan) olmak üzere ayrı kalemler olarak kaydedildiği, muhasebe kayıtlarının gelirler kısmında zaten belirtilmişti. Tahsil edilmemiş gelirler aynen hesap defterinde de listelenmiştir. Böylece gelir toplamada bazı zorlukların ortaya çıktığı köyleri tespit edebiliriz. Örneğin, birinci hesap defterinin sonunda listelenen aynî olarak toplanmamış 23 bâkî gelir kaleminin 9'u Halhol, Edna, Mecdil, Latani, Gayât, Harsa, Duri, Meşie, Kubâb-1 kuva köyleri ahalilerinin zimmetlerinde kalan vakıf gelirleri olmuştur. Bunun yanı sıra cari yılda söz konusu hesap defterinde kayıtlı vakıf köyler halkından ve vakıflardan (vergi tahsildarları) tahsil edilmeyen gelirlerin yanı sıra cari yılda mütevelli zimmetinde kalan vakıf geliri de yazılmıştır. 
Aşağıda, 1705-1707 yılları için el-Halil'deki Halilurrahman Vakfi'nın birinci hesap defterinden alınmış el-bâkî (kalan) kısmı tablo halinde sunulmuştur.

Tablo 17

Vakfin I. Muhasebe Kaydında Kalan Gelirler

\begin{tabular}{|c|c|c|}
\hline No & El-Bâkî & Tutarı \\
\hline 1 & $\begin{array}{l}\text { Der-zimmet-i ahâli-i karye-i Halhol be-mûceb-i defter-i Nâib en-Nâhiye. } \\
\text { Hinta keyl } 6 \\
\text { Şâ 'ir keyl } 10 \\
\text { Nakid }\end{array}$ & $\begin{array}{l}5.180 \\
1.920 \\
1.860 \\
1.500\end{array}$ \\
\hline 2 & $\begin{array}{l}\text { Der-zimmet-i ahâli-i karye-i Edna be-mûceb-i defter. } \\
\text { Hinta keyl } 402 \\
\text { Şâ ir keyl } 40\end{array}$ & $\begin{array}{c}21.600 \\
13.000 \\
6.200\end{array}$ \\
\hline 3 & Der-zimmet-i ahâli-i Mecdil hâsıl. & 400 \\
\hline 4 & Der-zimmet-i ahâli-i karye-i Latani hınta ve şa'îr ve nukud be-mûceb-i defter-i kâtib. & 11.863 \\
\hline 5 & Der-zimmet-i ahâli-i karye-i Gayât bahâ-i gllal be-mûceb-i defter-i kâtib. & 14.680 \\
\hline 6 & Der-zimmet-i ahâli-i Harsa be-mûceb-i defter-i kâtib. & 360 \\
\hline 7 & $\begin{array}{l}\text { Der-zimmet-i ahâli-i karye-i Duri be-mûceb-i defter-i kâtib en-Nâhiye. } \\
39942 \text { para } \\
\text { Hinta keyl } 52 \\
\text { Şâ ir keyl } 53 \text { Nakid } 11842 \text { para }\end{array}$ & $\begin{array}{c}39.942 \\
11.842 \\
18.720 \\
9.360\end{array}$ \\
\hline 8 & Der-zimmet-i el-Hac Hasan müste'cir-i Hanü'l-Acem der-Medineti Şam eş-Şerif. & 5.000 \\
\hline 9 & $\begin{array}{l}\text { Der-zimmet-i ahâli-i karye-i el-Meşie an-mahsûl-ı karye-i ..... } \\
\text { Hinta keyl } 15 \\
\text { Şâ 'ir keyl } 15\end{array}$ & $\begin{array}{l}3.900 \\
1.950\end{array}$ \\
\hline 10 & $\begin{array}{l}\text { Der-zimmet-i ahâli-i karye-i el-Kubab-l kova. } \\
\text { Edresi keyl } 25 \\
\text { Hınta keyl } 25\end{array}$ & $\begin{array}{l}3.750 \\
8.000\end{array}$ \\
\hline 11 & Der-zimmet-i câbi-i nâhiye-i Haleb Nakid ulufiye ve harc-l Vali-i.....el-vakf-l şerif. & 9.640 \\
\hline 12 & Der-zimmet-i Câbi-i Medine-i Misır an-malı sene 1117 gayri'l-gllal. & 9.600 \\
\hline 13 & Der-zimmet-i Ahmed Ağa zâbıt-l el-Münzi an-maktu-i sekiz kırat karye-i Errimsa. & 2.400 \\
\hline 14 & Der-zimmet-i Şeyh Abdullah Alemi müste'cir-i nâhiye-i Nablus. & 9.000 \\
\hline 15 & Der-zimmet-i Hamdan el-Gardi kova. Ezriye keyl 4 & 640 \\
\hline 16 & Der-zimmet-i ahâli-i karye-i Letruni. Ezriye keyl 40 & 640 \\
\hline 17 & $\begin{array}{l}\text { Der-zimmet-i ahâli-i Beyti Luba } \\
\text { Hinta keyl } 80 \\
\text { Ezriye keyl } 20\end{array}$ & $\begin{array}{l}2.720 \\
3.200 \\
\end{array}$ \\
\hline 18 & Der-zimmet-i Salih Uveyza.Ezriye keyl 4 & 640 \\
\hline 19 & $\begin{array}{l}\text { Der-zimmet-i Ahmed es-Esmadar. } \\
\text { Hinta keyl } 5 \\
\text { Şâ'ir keyl } 5\end{array}$ & $\begin{array}{c}1.600 \\
800\end{array}$ \\
\hline 20 & $\begin{array}{l}\text { Der-zimmet-i ahâli-i Beyti Banala. } \\
\text { Hinta keyl } 5 \\
\text { Şâ ir keyl } 5 \\
\text { Zeyt kıyye } 50 \\
\text { Koton klyye } 100\end{array}$ & $\begin{array}{c}1.600 \\
800 \\
2.000 \\
600\end{array}$ \\
\hline 21 & Der-zimmet-i ahâli-i Sevvakin Serefseta. Ezriye keyl 13 & 2.080 \\
\hline 22 & Der-zimmet-i Salih ibni Musllh. Hinta keyl 2 & 240 \\
\hline 23 & Der-zimmet-i Şeyh Salim Abdurrezzak. Hinta keyl 2 & 240 \\
\hline \multicolumn{2}{|r|}{ Toplam } & 169.468 \\
\hline
\end{tabular}


Vakfın yukarıda işaret edilen ve mütevelli zimmetinde kalan bâkî ise şöyle kaydedilmiştir: “Sahha'l-bâki ilâ Hazreti Aynü'l-A'yân Hasan Ăga el-mütevelli ale'l-vakfi'ş-şerif ziyâde-i an'l-irâd.49.147 para." Bu durumda da cari yılda vakıf köyler ahalilerinde kalan buğday, arpa, pirinç, zeytinyağı, koton mahsulleri ile kiracılarda kalan nukûd ve mütevelli zimmetinde kalan miktarla birlikte vakfın el-bâkî gelirleri toplamı 218.615 para olmuştur.

Vakfa ait İkinci muhasebe kaydında ise el-bâkî kısmı tek kalemde şöyle kaydedilmiştir.

El-bâki 169.468 para.

Muhasebe-i zimem-i re 'âyâ-yı kurahâ-i vakf-ı mezkurîn.

Dîde-i re 'âyâ kurahâ-i vaklf' an-baha-i hınta ve şa 'îr ve ezriye ve ruğan-l zeyt ve dîde-i müste'cirîn-i han ve hammamât 'an-mahsul-l vakfi dîde-i hod şah 'în kadrî para bâkî-i Mart vâcib sene 1118 ber-mûceb-i defter-i karye-i ....kâtib-i vakuf.

169.468 para

Bu başlıkta da yine vakıf köylerinin ahalisinin zimmetinde kalan buğday, arpa, pirinç ve zeytinyağı gelirleri ile vakfın han ve hamamlarında kalan kiracıların zimmetinde kalan nukûd kaydedilmiştir. Mütevelli zimmetinde kalan bir gelir yazılmamıştır.

\section{Değerlendirme ve Sonuç}

Sonuç olarak, mevcut çalışmada Halilürrahman Vakfı'nın 18. yüzyılın başına tarihlenen iki muhasebe kaydında yer alan toplam gelir ve gider rakamları meydana getirilmiş ve daha sonra ayrıntılı bir analiz geliştirmek için bunları bileşenlerine ayrıştırma yöntemi kullanılmıştır. Böylece vakıf köyü gelirleri, vakıf gelirlerini oluşturan önceki yıla ait nakdi fazla ve tahsil edilmemiş gelirler ayrı ayrı belirtilmiştir. Vakıf harcamalarını birlikte oluşturan personel giderleri, anbar, mutfak, aydınlatma harcamaları, onarım harcamaları ve muhtelif giderler de aynı şekilde ifade edilmiştir. Bu hesaplar bize el-Halil'deki Halilurrahman Vakfı'nın gelir kaynaklarının çeşitliliğini ve kompozisyonunu göstermektedir. Ayrıca, bu gelir kayıtlarından elde edilen veriler vakfın mali durumunu takip etmemizi sağlamaktadır. Hesap defterlerinin gider tarafının incelenmesi, vakıf mali tablosunu tamamlamıştır. Gıda ve diğer düzenli olarak tüketilen ürünler için yapılan harcamalar, imâret-vakıf (simât-ı kerîm ya da Halil İbrahim Sofrası)'ın işleyişi ve hizmetleri için bize önemli bilgiler sunmuştur.

Buna göre öncelikle Halilürrahman Vakfi'nın gelir kalemleri değerlendirildiğinde hatırlanması gereken husus vakfın el-Halil kentinde mukîm fakir ve muhtaçlar ile hacılar, sufiler ve seyyahların ağırlandığı bir sofrayı bünyesinde bulundurmasıdır. Bu sofra, Halilürrahman vakıf külliyesinin en önemli yapısı olarak külliyeye kendi adını vermiştir. Temelde vakıf, açların doyurulması için hizmet sunan bir imâret-külliyedir. $\mathrm{Bu}$ imârette pişirilen yemeklere bakıldığında ise, örneğin, 16. yüzyıl başlarında kenti ziyaret eden yerel vakanüvis Mucireddin el-Hanbelî (öl. 927/1521) imârette perşembe akşamları iç pilavla (ruzzü'l-mufalfal) nar tanesi ikram edilirken, sofradaki günlük tayının mercimek çorbası 
olduğunu gözlemlemişti. Bayramlarda ise daha zengin yemekler pişirildiğinden bahisle imârette Cuma ve bayram günlerinde ziyaretçilere farklı bir menü sunulduğuna işaret etmiştir. Mucireddin sofralardaki günlük kurallara da yer verdiği çalışmasında imârette ekmeğin günlük pişirildiğini ve günde üç kere dağıtıldığını belirtir. Her gün pişen ekmeğin miktarının 14.000 yassı somun olduğunu, bu rakamın bazı zamanlarda 15.000'i bulduğunu kaydeder. Herkesin buyur edildiği sofranın kapasitesinin tespitinin ise zor olduğuna işaret eder. Mucireddin ayrıca imârette ikram edilen yemeği buğday aşı anlamına gelen deşişe olarak adlandırır. Memluk Sultanı Kayıtbay'ın da deşişe adı verilen buğday ve yağdan oluşan bu yemeğin dağıtılmasını şart kıldığı Medine'deki imâreti için el-Halil'de bulunan imâreti örnek aldığını belirtir ${ }^{31}$. 17. yüzyıl seyyahlarından Evliya Çelebi ise Mucireddin'den yaklaşık iki yüz yıl sonra ziyaretinde kaleme aldığı seyahatnamesinde simâtı anlatırken bu imârette dağıtılan buğday çorbasının lezzetini hiçbir vezir sofrasında bulamadığını kaydeder. Bunun yanı sıra, Halilürrahman imâretinde her gün 7.000 sahan yemek dağıtıldığından ve şehirdeki zengin-fakir bütün halkın evinde yemek pişirmeyip herkesin bu sofradan geçindiğinden bahseder ${ }^{32}$.

Simâtta 18. yüzyılda sunulan yemekler hakkında ise, Dîvân-1 Hümâyun'a Haremeyn-i Şerifeyn Evkâfı nâzırı Dârüssaâde Ağası el-Hac Beşir Ağa tarafından gönderilen arz üzerine kaleme alınan 17 Safer 1193/6 Mart 1779 tarihli emr-i şerîfte şöyle bahsedilmiştir:

"... bâfermân-l 'âlîmahfûz olan defterde vakf-l șerîf-i mezkûre kurâ ve mezâri 'vâridâtından vezâyif-i hademe ve simât- kerîm mesârife ve ta 'yinât ve emânât-ı misafirîn ve mücâvirîn ve muhtacîn içün tabh olunan nân-ı azîz ve şorba içün hınta ve pilav ve zerde içün pirinç ve lahm ve hatab ve zehâyir-i sâire ve şem'-i 'asel bahaları ve mesârıf-i ta 'mirât ve levâzımı mühimmeye sarf olunmak üzere târîh-i mezkûrede olan mesârıfin mecmu' ' dokuz bin sekiz yüz yirmi kuruşa bâliğ olmuş olmadiğı ... ",33

Bu kayıtta vakfin köy ve mezraa gelirlerinden görevli ücretleri ve simât-l kerîmin masrafları, tayinatlar ile misafir ve mücâvir ve ihtiyaç sahipleri için pişirilen ekmek ve çorba için buğday; pilav ve zerde için pirinç, et ve odun ve diğer hububatlar ve balmumu ücretlerine ve tamir masrafları ile diğer önemli ihtiyaçlar için söz konusu tarihte masrafların toplamının 9.820 kuruşa denk gelmediği kayıtlıdır. Bu bilgiden yukarıda detaylı bir şekilde incelenen muhasebe kayıtlarında yazılan vakfın gelir ve gider kalemlerini kabaca tespit etmek mümkündür. Öte yandan, bu hüküm simâtta pişirilen yemekler ve vakıftan yararlananlar hakkında da bilgi verir. Yani, 18. yüzyılın ortalarına ait bu kayıtta simâta gelenlere ekmek, buğday çorbası ve zerde pişirildiği görülmektedir. Bu da imâretteki etkinliğin 18. yüzyılın ortasında da gelenek olduğu üzere devam ettiğine işaret eder.

31 Mucireddin el-'Uleymî el-Hanbelî, el-Ünsü'l-Celîl bi-Târîhi'l-Kudsi ve'l-Halîl, c. II, Mektebetü'l-Muhtesib, Amman 1973, s. 94.

32 Evliya Çelebi, Seyahatnâme, c. IX (1671-72), Devlet Matbaası, İstanbul 1935, s. 510.

33 VGMA, 815, 144-145. 
Dolayısıyla imâretin işleyişi ve ikram edilen yemeklere bakıldığında muhasebe kayıtlarında yer alan gelir kalemleri daha da anlamlı hale gelmektedir. Şöyle ki, I. Muhasebe kaydında \%55,88'e ve II. Muhasebe kaydında da \%55,34'e tekabül eden köylerin hâsılatından gelen tarımsal ürünler arasında kaydedilen buğday, arpa, pirinç, zeytinyağı mahsulleri vakfın imâretinin mahsul kaynağını oluşturmuş gözükmektedir ${ }^{34}$. Aynı şekilde vakfın kentsel gelirlerini oluşturan gelirler de vakıf bütçesi içerisinde önemli bir yere sahip olmuştur. Böylece çalışma çerçevesinde tablolar halinde sunulan bu gelirler vakfın kentsel olduğu kadar kırsal etkinliğini de göstermektedir. Benzer şekilde muhasebe kayıtlarında listelenen ve bir kısmı tablolar halinde sunulan vakıf gelirleri, vakfın yalnızca el-Halil nâhiyesinde değil, aynı zamanda Kudüs nâhiyesi, Gazze sahili, Beni Süheyle, Remle sahili, Nablus nâhiyesi, Beni Sa 'b, Haleb, Şam ve Misır nâhiyelerinde bulunan musakkafât ve müstegallât gelirleri de vakfın bölgesel etkinliğine ve ekonomik faaliyetlerine ilişkin fikir vermektedir.

Vakfın gider kalemleri arasında en geniş harcama kalemlerini oluşturan personel giderlerinin kayıtlarına gelince, bu kayıtlar Halilurrahman vakfında mevcut olan bölünmeleri ve çalışan sayısını ortaya koymaktadır. Vakıf faaliyetlerinin yanı sıra vakıf gelirlerinin tahsilâtı ve dağıtımında yer alan 252 kişi vakfın görevlileri olarak listelenmiştir. Vakıf yönetim kadrosu vakıf giderlerinden aslan payını alırken vakfın genel hizmetli personelinin sayıca çokluğu dikkat çekmiştir. Çoğunlukla Haremü'l-Halil'de bulunan Peygamber makamlarının temizliği, bakımı, aydınlatılması ve kapıcılığı bu başlıktaki görevlilerce yerine getirilen hizmetler olarak kaydedilmiştir. Harem-i şerif imamları, hatipleri, müderris ve müezzinleri de sayı ve maaş bakımından vakıf bütçesinin önemli gider kalemlerini oluşturmuştur. Vakıf gelirlerinin kaydedilmesi ve tahsil edilmesinden sorumlu kâtip ve câbîler de vakıf görevlileri arasında sayıca fazladır. Simât, anbar eminleri, anbardar, çavuşlar, Hanbelîlerin ileri gelenlerinin ücretleri, dinleyiciler sosyal hizmet ve genel hizmet kategorilerinde değerlendirilen diğer vakıf görevlileridir. Vakfa ait I. Muhasebe kaydında mütevelli, kâtip ve müderris gibi görevlilere her sene bir miktar buğday, arpa ve zeytinyağı tahsis edilmişken, örneğin genel hizmet görevlileri için bu tür bir tahsisat söz konusu değildir.

Görevli ücretlerinin yanı sıra vakfın işleyişi için gerekli olan masraflar ile simâtın kent halkına ve ziyaretçilere sunduğu yemek masrafları diğer gider kalemlerini oluşturmuştur. Bu masraflar arasında tamir masraflarının azlığı nazarı dikkate sunulmuştur.

Netice itibariyle bu çalışma Halilürrahman Vakfı örneğinde Osmanlı muhasebesinin detaylarının anlaşılmasının, kayıtların uygun şekilde istihdam edilmesinin bir ön koşulu olduğunu göstermeye çalışmıştır. Bu muhasebe defterlerinin sahip olduğu büyük potansiyel göz önüne alındığında, daha fazla araştırmaya ihtiyaç olduğu açıktır. Bu nedenle, muhasebe kayıtlarının belge olarak yakından incelenmesi esastır. Özellikle Osmanlı dönemi Bilâd-1 Şam coğrafyası için bu yönde çalışmaların yapılması elzemdir.

34 Bkz. Tablo 2, 6. 
Hakem Değerlendirmesi: Dış bağımsız.

Çıkar Çatışması: Yazar çıkar çatışması bildirmemiştir.

Finansal Destek: Yazar bu çalıșma için finansal destek almadığını beyan etmiștir.

Peer-review: Externally peer-reviewed.

Conflict of Interest: The author has no conflict of interest to declare.

Grant Support: The author declared that this study has received no financial support.

\section{Kaynakça/References}

\section{Arşiv Kaynakları}

Türkiye Cumhuriyeti Cumhurbaşkanlığı Devlet Arşivleri Başkanlığı Osmanlı Arşivi (BOA)

Evkâf-1 Haremeyn Muhasebeciliği Defterleri (EV.HMH.d), 1431.

\section{Vakıflar Genel Müdürlüğü Arşivi (VGMA)}

Ahkâm-ı Mekke ve Medine ve Misır, 814, 815.

\section{Kitap ve Makaleler}

Akgündüz, Ahmet, Osmanlı Kanunnameleri, İstanbul 1994, c. VII.

Akkaya, Yasemin, XIX. Yüzyılda Kudüs ve Çevresinde Halilü'r-Rahman Vakıfları, Afyon Kocatepe Üniversitesi Sosyal Bilimler Enstitüsü, Yüksek Lisans Tezi, Afyon 2012.

Armağan, A. Latif, “XVIII. Yüzyılda Hac Yolu Güzergâhı ve Menziller”, Osmanlı Araştırmalarl, sayı XX, İstanbul 2000, s. 73-76.

Atalar, Münir, Osmanlı Devleti’nde Surre-i Hümâyûn ve Surre Alayları, Diyanet İşleri Başkanlığı Yayınları, Ankara 1991.

Bakhit, Muhammad A., The Ottoman Province of Damascus in the Sixteenth Century, Librairie du Liban, Beirut 1982 .

Barbir, Karl K., Ottoman Rule in Damascus, 1708-1758, Princeton University Press, Princeton 1980.

Barkan, Ömer L., “Ayasofya Cami’i ve Eyüb Türbesinin 1489-1491 y1llarına Ait Muhasebe Bilançoları”, Istanbul Üniversitesi iktisat Fakültesi Mecmuast, XXIII/1-2 (1962-63), s. 342-379.

, "Edirne ve Civarındaki Bazı Imaret Tesislerinin Yıllık Muhasebe Bilançoları", Belgeler, I/2 (1964), s. 235-377.

, "Fatih Cami ve İmareti Tesislerinin 1489-1490 Yıllarına Ait Muhasebe Bilançoları", İstanbul Üniversitesi İktisat Fakültesi Mecmuası, XXIII/1-2 (1962-63), s. 297-341.

, “İmaret Sitelerinin Kuruluş ve İşleyiş Tarzına Ait Araştırmalar”, İstanbul Üniversitesi İktisad Fakültesi Mecmuası, XXIII/1-2 (1962-63), s. 239-296.

, "Süleymaniye Cami ve İmareti Tesislerine Ait Yıllık Bir Muhasebe Bilançosu 993/994

(1585/1586)", Vaklflar Dergisi, say1 9 (1971), s. 109-112.

Bilge, Mustafa L., "Halil”, DIAA, c. XV, İstanbul 1997, s. 305-306. 
Durmuş, M. Emin - İsmail Bektaş, “Osmanlı'da Muhasebe Usulü ve Vakıf Muhasebe Kayıtları Okuma Kılavuzu”, Pesa Uluslararası Sosyal Araştırmalar Dergisi, III/2 (2017), s. 196-209.

Emecen, F. M., "Fodula”, DIA, c. XIII, İstanbul 1996, s. 167-170.

Evliya Çelebi, Seyahatnâme, c. IX (1671-72), Devlet Matbaası, İstanbul 1935.

Faroqhi, S., "Seyyid Gazi Revisited: The Foundation as Seen Through Sixteenth and Seventeenth Century Documents", Turcica, 1981, s. 90-121.

, "Vakıf Administration in Sixteenth Century Konya, The Zaviye of Sadreddin-i Konevi", Journal of the Economic and Social History of the Orient, XVII/2 (1974), s. 145-172.

Fişne, Rahime, XVIII. Yüzyıl Başlarında Kudüs Surresi (Transkripsiyon ve Değerlendirme), Afyon Kocatepe Üniversitesi Sosyal Bilimler Enstitüsü, Yüksek Lisans Tezi, Afyon 2012.

Gerber, Haim, Economy and Society in an Ottoman City: Bursa, 1600-1700, The Hebrew University, Jerusalem 1988.

Gülen, Ayşenur, Kudüs Ahalisi Surresi: Transkripsiyon ve Tahlil (1593-1623), Fatih Sultan Mehmet Üniversitesi Sosyal Bilimler Enstitüsü Tarih Bölümü, Yüksek Lisans Tezi, İstanbul 2019.

Güler, Mustafa, “Halilürrahman’ın Dura Köyünde 1863 Yılında Yaşanan Bir Asayiş Meseleri”, Filistin Araştırmaları Dergisi, Kudüs Özel Sayısı, sayı 2 (Kış 2017), s. 58-75.

, “Hz. İbrahim'den Bugüne Uzanan Tarihi ile Halilürrahman vakfi bir Filistin köyü: Halhul”, Osmanlı Döneminde Kudüs Uluslararası Sempozyumu, İstanbul 29-30 Nisan 2017.

,"The Role of the Ottoman Waqfs in the Solution of the Issue of Hebron with a Favor of Muslims," Osmanlı Medeniyeti Araştırmaları Dergisi, II/2 (Ocak 2016), s. 27-35.

, Osmanlı Devletinde Haremeyn Vakıflarl (16. ve 17. Yüzyıllar), Çamlıca Yayınları, İstanbul 2011.

Güneş, Hasan H., “17. Yüzyılda Kudüs Halilürrahman Vakfı Görevlileri ve Vakfın İşleyişindeki Rolleri”, Journal of History Culture and Art Research, VII/1, s. 647-662.

Güvemli, Batuhan - Özcan Unutkan, "The Practice of Merdiban Method in State Accountancy According to Ottoman Documents", Muhasebe ve Finans Tarihi Araştırmaları Dergisi, sayı 11 (Temmuz 2016), s. 71-110.

Güvemli, Oktay, Muhasebe Tarihi, Avcıl Basım Yayım, İstanbul 1995.

- Batuhan Güvemli, “Osmanlı Kayıt Kültüründe Vakıf muhasebesi ve Devlet Muhasebe Sistemi”, Vakıflar Dergisi, say1 46 (2016), s. 9-10.

Halaçoğlu, Y., Osmanlı Imparatorluğunda Menzil Teşkilatı ve Yol Sistemi, İstanbul Üniversitesi Edebiyat Fakültesi Yay., İstanbul 1982.

el-Hanbelî, Mucireddin el-‘Uleymî, el-Ünsü'l-Celîl bi-Târîhi'l-Kudsi ve'l-Halîl, c. II, Mektebetü'l-Muhtesib, Amman 1973.

İnalcık, Halil, "Weights and Measures", An Economic and Social History of the Ottoman Empire, der. H. İnalcık - D. Quataert, c. I, Cambridge University Press, Cambridge 1997.

Marcus, Abraham, The Middle East on the Eve of Modernity: Aleppo in the Eighteenth Century, Columbia University Press, 1989.

Meier, A., "For the Sake of God Alone? Food Distribution Policies, Takiyyas and Imarets in Early Ottoman Damascus,", Feeding People, Feeding Power: Imarets in the Ottoman Empire, ed. Nina Ergin, Christoph K. Neumann, Amy Singer, Eren Yayınları, İstanbul 2007, s. 121-47. 
Memiş, Şerife E., “'Nebzetü’l-Menâsik': en-Nakşibendî el-Muradî’nin Hac Rehberi'nde Kudüs Bahsi”, Dini Tarihi ve Edebi Açıdan Kudüs, DBY Yay., İstanbul 2018, s. 170-173.

, Osmanlı Taşra Toplumu ve Vakıf Kurumu: Kudüs, 1703-1831, Hacettepe Üniversitesi Sosyal Bilimler Enstitüsü Tarih Bölümü, Doktora Tezi, Ankara 2016.

Orbay, Kayhan, "Account Books of the Imperial Waqfs (Charitable Endowments) in the Eastern Mediterranean (15th to 19th Centuries)", Accounting Historians Journal, say1 40 (2013), s. 31-50.

, "Imperial Waqfs within the Ottoman Waqf System", Endowment Studies, I/2 (2017), s. 145-146.

, "Structure and the Content of the Waqf Account Books as Sources for Ottoman Economic and Institutional History", Turcica, Revue D'Etudes Turques, say1 39 (2007), s. 3-48.

, The Financial Administration of an Imperial Waqf in an Age of Crisis: A Case Study of Bâyezîd II's Waqf in Amasya (1594-1657), Bilkent Üniversitesi Tarih Bölümü, Doktora Tezi, Ankara 2001.

, "Vakıfların Bazı Arşiv Kaynakları; Vakfiyeler, Şeriye Sicilleri, Mühimmeler, Tahrir Defterleri ve Vakıf Muhasebe Defterleri”, Vakıflar Dergisi, sayı 29 (2006), s. 27-41.

, "Vakıf Muhasebesi ve Kurumsal Etkinlik: Kayıt Sistemi, Defterler, Denetim”, XVII. Türk Tarih Kongresi, Ankara, Türkiye, 15 - 17 Eylül 2014, c. IV, no. 5, s. 1719.

, "Muhasebe Defterlerine Göre 17. Yüzyıl Başlarında Üç Şerefeli Camii Vakfi”, H.Ü. Türkiyat Araştırmaları", sayı 15 (2011), s. 159-165.

Orhonlu, Cengiz, Osmanlı İmparatorluğunda Derbend Teşkilatı, Eren Yay., İstanbul 1990.

Öztürk, Said, Osmanlı Arşiv Belgelerinde Siyakat Yazısı ve Tarihi Gelişsimi, OSAV, İstanbul 1996.

Pakalın, Mehmed Z., Osmanlı Tarih Deyimleri ve Terimleri Sözlüğü, c. I, MEB Yay., İstanbul 2004.

Singer, Amy, Osmanlı'da Hayırseverlik - Kudüs 'te Bir Haseki Sultan İmareti, çev. Dilek Şendil, Tarih Vakfı Yurt Yayınları, İstanbul 2004.

Şensoy, Fatma, “Ebubekir Paşa'nın İstanbul'daki Sıbyan Mektebi ve Sbil Vakfı'nın 1867-68 Yıllarına ait

Muhasebe Defterleri Üzerinden Vakıflardaki Kayıt Düzeni ve Dinamik Yapı”, Akademik İncelemeler Dergisi, 13 (1), Sakarya 2018, s. 391-416.

"Muhasebe Defterlerinden Vakıfların Çok Yönlü Boyutlarını İzlemek-Bir Örnek XVIII. Yy.", Muhasebe ve Finans Tarihi Vakfi (MUFTAV), sayı 7 (2014), s. 76-103.

- Oktay Güvemli, "The State Accounting Doctrine Book of The Middle East In The XIV Century:

Risale-i Felekiyye-Kitab-us Siyakat And Its Place in Accounting Culture", The British Accounting Review, 47 (2015), s. 159-176.

Uluçam, A., "Haremü'l- Halîl”, DIA, c. XV, İstanbul 1997, s. 308.

Uslu, Özge, 1144 numaralı Kudüs-i Şerif Surre Defteri (M. 1620-21/H. 1030) (Transkripsiyon-Değerlendirme),

Kırklareli Üniversitesi Sosyal Bilimler Enstitüsü Tarih Bölümü, Yüksek Lisans Tezi, Kırklareli 2019.

Uzunçarş11, İ. H., Mekke-i Mükerreme Emirleri, Ankara 1972.

Ze'evi, D., XVII. Yüzyılda Bir Osmanlı Sancağında Toplum ve Ekonomi, Tarih Vakfı Yurt Yay., İstanbul 2000. 


\section{Ek}

Vakfın 1118 (1707-1708) tarihli ikinci muhasebe kaydına göre el-Halil Nâhiyesi gelirleri.

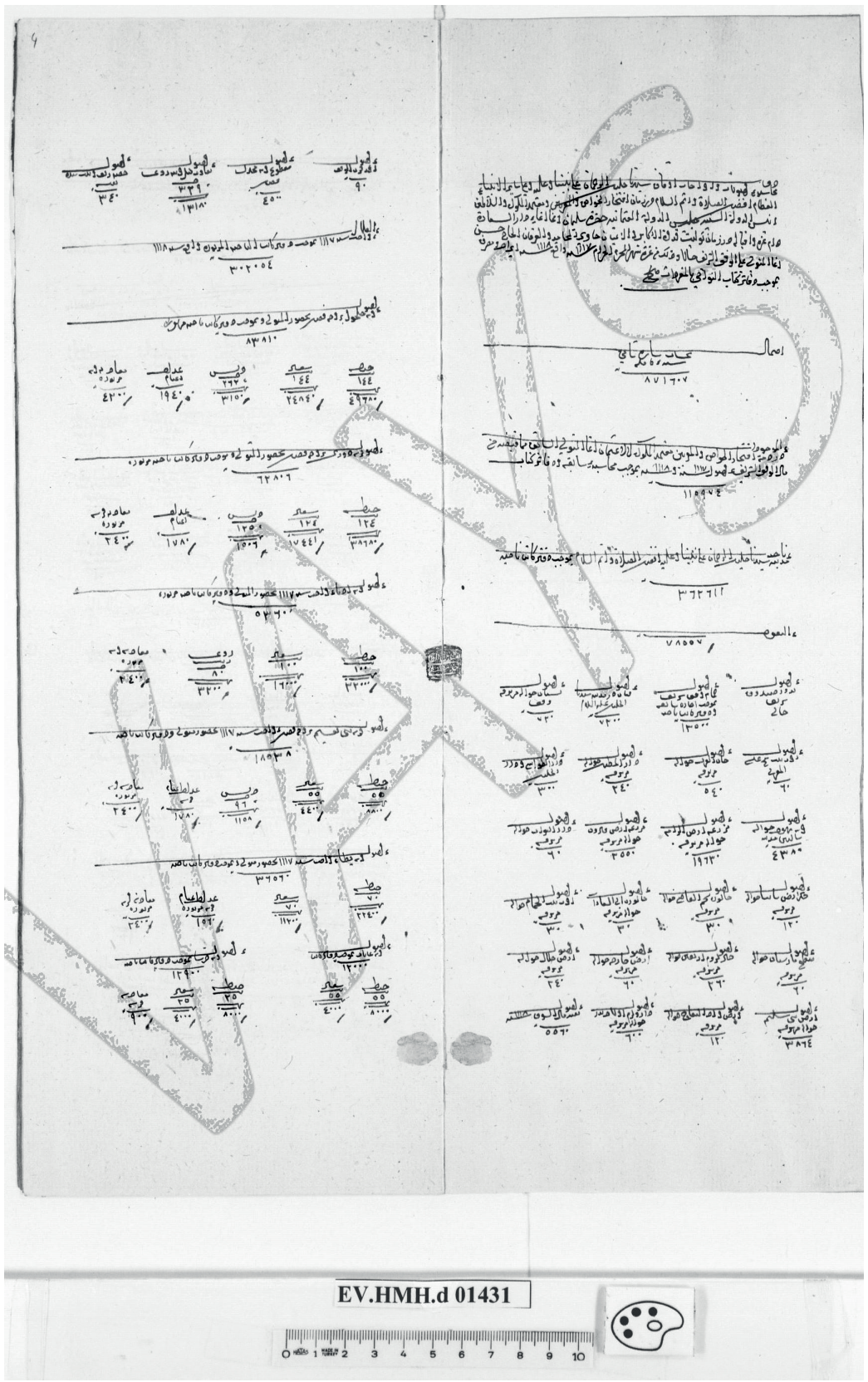

